\title{
The Application of Fungi for Bioleaching of Municipal Solid Wastes for the Production of Environmental Acceptable Compost Production
}

\author{
Jwan J Abdullah ${ }^{1,2}$, Amina Ahmed El-Imam ${ }^{1,4}$, Darren Greetham ${ }^{1}$, Chenyu Du ${ }^{3}$ and \\ Gregory A. Tucker ${ }^{1 *}$ \\ ${ }^{1}$ University of Nottingham, School of Biosciences, Sutton Bonington Campus, Loughborough, LE12 5RD, UK \\ ${ }^{2}$ University of Salahaddin - Hawler (Erbil) College of science, Department of environment, Iraq \\ ${ }^{3}$ University of Huddersfield, School of Applied Science, Huddersfield, HD1 3DH, UK \\ ${ }^{4}$ Microbiology Department, Faculty of Life Sciences, University of Ilorin, P.M.B. 1515, Ilorin Nigeria
}

*Corresponding Author: Gregory A. Tucker, Bioenergy and Brewing Sciences Building, Sutton Bonington Campus, Sutton Bonington, Leicestershire, LE12 5RD, UK, Tel: 01159516126; Fax: 01159516122; E-mail: gregory.tucker@nottingham.ac.uk

Received: 11 July 2017; Accepted: 22 August 2017; Published: 05 September 2017

\begin{abstract}
Analysis of the chemical components of Municipal solid waste (MSW) indicated that the presence of high concentrations of toxic heavy metals. The aim of this study was to select the best leaching condition, in order to generate a compost product, which adheres to the environmental standards for safe use.
\end{abstract}

To determine the role of organic acids produced in the bioleaching process, chemical leaching experiments were compared using inorganic $\left(\mathrm{H}_{2} \mathrm{SO}_{4}\right)$ or organic acids (oxalic, and gluconic acids). These results revealed that addition of $\mathrm{H}_{2} \mathrm{SO}_{4}$ correlated with a lower retained yield when comparing with addition of the other acids. Bioleaching was then studied by culturing fungi on the MSW. Addition of Aspergillus niger correlated with an efficient removal of heavy metal elements. The effect of $\mathrm{pH}$ was also determined and assays at $\mathrm{pH} 5.5$ using a clay medium (32.4\%) or at pH 2.5 using a sorghum medium (28\%) were characterised by a lower retained yield. In the above conditions, we looked at elemental ions which have been deemed beneficial to the environment ( $\mathrm{P}$ and $\mathrm{K}$ ) and those which are toxic $(\mathrm{Cd}, \mathrm{Cu}, \mathrm{Cr}, \mathrm{Ni}, \mathrm{Pb}$ and $\mathrm{Zn})$, these elements were measured in the solid fractions. 
Keywords: MSW; Bioleacing; Chemical bioleaching; Clay; Sorghum; Organic; Inorganic acids

\section{Introduction}

Municipal Solid Waste (MSW) is a complex material which varies greatly in composition. Some of these components are stable, while others degrade as a result of biological and chemical processes which causes environmental pollution [1]. For this reason, solid waste management is the main process for the reduction of the effect of pollution in the environments. In most of countries solid wastes in land fill (open dump sites) is the most common means of disposal. The sites are unsanitary, generally smelly, and they attract undesirable animals and insects [2]. Furthermore, the leachate resulting from these sites contains hazardous pollutants to the soil and ground water, levels of these pollutants can reach dangerous levels, so the leaching metals into the soil leads to the contamination of soil, groundwater and air (acid rain) [3].

A health and safety issue arises from improper management of MSW, the World Health Organization (WHO) estimates that about a quarter of the diseases facing mankind today occur due to prolonged exposure to environmental pollution [4]. Using water polluted by MSW for bathing, food irrigation and drinking water can also expose individuals to disease organisms and other contaminants [5]. Soil pollution contaminated by heavy metals is another issue where leaching has been shown to have an effect on plants or when used as compost and the presence of these heavy metals has been shown to damage soil quality and fertility in soil [6]. Contaminants like cadmium $(\mathrm{Cd})$, copper $(\mathrm{Cu})$, nickel $(\mathrm{Ni})$, lead $(\mathrm{Pb})$ and zinc $(\mathrm{Zn})$ can alter the soil chemistry and have an impact on the soil organisms and plants [7].

To improve soils physical properties, organic material plays an important role in helping to replenish soil organic matter levels, supply nutrients such as nitrogen $(\mathrm{N})$, phosphorus $(\mathrm{P})$ and potassium $(\mathrm{K})$, and other essential elements to plants. Addition of organic material improves soil structure, water holding capacity, and has an beneficial effects on microbial biomass and activity [8].

Composting is one of several methods for treating bio solids to create a marketable end product that is easy to handle, store, and use. However, the end product is usually a Class A, humus-like material without detectable levels of pathogens that can be applied as a soil conditioner and fertiliser [9-11]. Compost production is normally produce by two methods, it is usually an aerobic process, but recently an anaerobic pre-treatment of MSW has also being utilized, followed by an aerobic curing step [12]. There are many methods for removal of metal and toxic elements from soil and compost such as hydrothermal [13]; subcritical water treatment [14]; chemical leaching using inorganic mineral acids like sulphuric acid, hydrochloric acid, and nitric acid [14], or use of chelating reagents like nitrilotriacetic acid (NTA) [13, 16], ethylene diamine tetra acetate (EDTA), and Diethylene Triamine Penta Acetate (DTPA) [16]. Use of alkaline solutions like ammonium and sodium hydroxides are also sometimes used. However, these treatments have some common disadvantages such as high cost and generating potential toxicity byproducts [17]. 
In recent years, bioleaching technology (biohydrometallurgical) has been widely used for the removal of heavy metals from waste. This process is considered to be a green technology with low-cost and low-energy requirements [17]. Microbial bioleaching is an approach which exploits the natural ability of microorganisms to transform solid compounds into a soluble and extractable form. This may involve enzymatic oxidation or reduction of the solid compound, or an attack on the solid compound by metabolic products [18].

There are three main groups of microorganisms which have been used for bioleaching process; autotrophic bacteria

(e.g. Thiobacilli spp.) [19] heterotrophic bacteria (e.g. Pseudomonas spp., Bacillus spp.) [20] and heterotrophic fungi (e.g. Aspergillus spp., Penicillium spp.) [17].

Several mechanisms are involved in bioleaching, including (i) acidolysis; (ii) complexolysis; (iii) redoxolysis; and (iv) bioaccumulation [21]. Compared to bacterial leaching, fungal leaching has the following advantages: (i) ability to grow under higher $\mathrm{pH}$, and thus is more suitable in bioleaching of alkaline solid waste; (ii) a generally faster leaching process with shorter lag phase; and (iii) ability to excrete metabolites (e.g. organic acids) to form complexes with metal ion, thus reducing metal toxicity in the biomass [22, 23]. However, operating costs are higher for fungal leaching (by heterotrophs) when compared with bacterial leaching (by autotrophs) due to the need for an organic carbon source for their growth and organic acid excretion. Acidolysis is the principal mechanism in bioleaching with Aspergillus niger; the fungus has been reported to produce organic acids such as citric, oxalic and gluconic acids during the bioleaching process $[22,23]$. The most important species of fungi in terms of their ability to produce abundant organic acids are A. niger and Penicillium simplicissimum [24].

The objective of this study was to investigate the bioleaching of MSW using either a one-step or two-step bioleaching method with $10 \%$ solid liquid ratio and incubation with fungi. The concentrations of elemental ions such as those termed beneficial $(\mathrm{P}$ and $\mathrm{K}$ ) and those termed toxic $(\mathrm{Cd}, \mathrm{Cu}, \mathrm{Cr}, \mathrm{Ni}, \mathrm{Pb}$, and $\mathrm{Zn}$ ) were determined in the solid fractions, during the bioleaching process and during the production of organic acids during the processes. Bioleaching was also compared with chemical leaching using inorganic or organic acids.

\section{Materials and Methods}

\subsection{MSW Chemical composition analysis}

Municipal solid waste (MSW) was supplied by Wilson Company in the UK. The lignocellulosic composition, lignin, protein and lipids analyses of the substrate have been described previously [25].

\subsection{Elements analysis}

Analysis of 28 elemental ions (including $\mathrm{P}, \mathrm{K}, \mathrm{Cd}, \mathrm{Cu}, \mathrm{Cr}, \mathrm{Ni}, \mathrm{Pb}$, and $\mathrm{Zn}$ ) followed a digestion method was as follows: $2 \mathrm{~g}$ MSW, $15 \mathrm{~mL}$ concentrated $\mathrm{HNO}_{3}$ were used for digestion on the hot plate, until the volume reached almost $5 \mathrm{~mL}$. Filter paper (No. 42) was used for sample filtration, and then deionized water was added to a total volume of $100 \mathrm{~mL}$. An Inductively Coupled Plasma Mass Spectrometer (ICP-MS) was used for the element analysis [26]. 


\subsection{Microorganisms}

Aspergillus niger N402 and Trichoderma reesei strains were kindly donated by Professor David Archer (University of Nottingham, UK). Aspergillus terreus was obtained from the DSMZ culture collection, Germany and was cultured according to the procedure in [27]. Six-day-old spores were harvested from Potato Dextrose Agar plate surface. The number of spores was counted using a haemocytometer and standardised to $1 \times 10^{7}$ spores $/ \mathrm{mL}$ of spore suspension.

\subsection{Media used for bioleaching}

2.4.1 Fungi artificial medium: The constituent of this artificial medium was based on the study by [17]. The medium was prepared containing g/L: glucose (60), $\mathrm{NaNO}_{3}$ (1.5), $\mathrm{KH}_{2} \mathrm{PO}_{4}(0.5), \mathrm{MgSO}_{4} \cdot 7 \mathrm{H}_{2} \mathrm{O}(0.025), \mathrm{KCl}(0.025)$ and yeast extract (1.6). Before autoclave at $121^{\circ} \mathrm{C}$ for $15 \mathrm{~min}$., the $\mathrm{pH}$ was adjusted 5.5 (for the usage as the initial artifical fungal medium) or 2.5 (for the usage as the final fermentation artifical fungal medium).

2.4.2 Clay medium: A 100\% pure clay (Terracotta Clay supplied by http://www.piscesart.co.uk/shops) was dried in an oven at $70^{\circ} \mathrm{C} .10 \mathrm{~g}$ of clay was mixed with $100 \mathrm{~mL}$ distilled water $(10 \%$ dry weight $)$ and the $\mathrm{pH}$ was adjusted according to experimental requirements, after the $\mathrm{pH}$ adjustment, the solution was sterilized by autoclave $\left(121^{\circ} \mathrm{C}\right.$ for $15 \mathrm{~min}$ ), the clay was mixed well before transfering into the flasks.

2.4.3 Sorghum bran medium: Milled sorghum bran was added to $1 \% \mathrm{H}_{2} \mathrm{SO}_{4}$ to give a $20 \% \mathrm{w} / \mathrm{v}$ solid loading and autoclaved at $121^{\circ} \mathrm{C}$ for $30 \mathrm{~min}$. The medium was adjusted to the required $\mathrm{pH}$ before being sterilized by vacuum filter sterilization $(0.45 \mu \mathrm{M})$, the resulting sample contained $56 \mathrm{~g} / \mathrm{L}$ glucose, and the $\mathrm{pH}$ was adjusted to either 5.5 or 2.5 .

\subsection{Chemical leaching}

Chemical leaching of the heavy metals was carried out using organic acids (oxalic and gluconic) and inorganic acids $\left(\mathrm{H}_{2} \mathrm{SO}_{4}\right)$ with a concentration of $0.5 \mathrm{M}$. Experiments were performed under the same conditions as for bioleaching i.e., $30^{\circ} \mathrm{C}$ and $120 \mathrm{rpm}$ and $10 \%(\mathrm{w} / \mathrm{v}) \mathrm{MSW}$. The organic and non-organic acids were selected according to literature [17]. Samples were collected after 7 and 15 days [28].

After 7 or 15 days of leaching, samples were centrifuged at $4472 \mathrm{~g}$, for $20 \mathrm{~min}$, the liquid fraction was decanted, whilst the solid fraction was washed three times using reverse osmosis distilled water (RO water) and dried at $70^{\circ} \mathrm{C}$, weight loss $(\%)$ in the solid fraction was determined and presence of heavy metals in solid fractions was determined.

After bioleaching process the samples were digested using strong acid as mentioned by [26]; then centerfuge and filtered through $0.45 \mu \mathrm{m}$ member filters before the elemental ions analysis such Boron (B), Sodium (Na), Magnesium (Mg), phosphorus (P), Sulphur (S), Potassium (K), Calcium (Ca), Thalium (Ti), Aluminum (Al), Vanadmium (V), Chromium (Cr), Manganese (Mn), Iron (Fe), Cobalt (Co), Nickel (Ni), Copper (Cu), Zinc (Zn), Arsenic (As), Selenium (Se), Rubidium (Rb), Strontium (Sr), Molybdium (Mo), Silver (Ag), Cadmium (Cd), 
Caesium (Cs), Barium (Ba), Lead $(\mathrm{Pb})$, and Uranium (U), finally the yield was determined in the solid fraction. For fungal bioleaching, besides the element composition analysis, the organic acids concentrations were also deteremined using ICP-MS.

The metal extraction efficiency was calculated as the\% recovery in the MSW:

- Starting concentation was calculated $\mathrm{mg} / \mathrm{kg}$

- Treatment -send solid residue for analysis $\mathrm{mg} / \mathrm{kg}$ but the recovery of solid residue is Net $100 \%$

- Calculate Solid residue retention (\%): MSW $1 \mathrm{~kg}$ of MSW has X amount of Fe for example; Treat $10 \mathrm{~g}$ of MSW has :

$$
\text { Formula }(A) \mathrm{mg}=\frac{\mathbf{F e}\left(\frac{\mathbf{m g}}{\mathbf{k g}}\right) * 10}{1000}
$$

Recover Y g of solid residue (dry weight) which has Z mg/kg of Fe, so total in residue is :

$$
\text { Formula }(B) \mathrm{mg}=\frac{Z * Y}{\mathbf{1 0 0 0}}
$$

Retained in residue is:

$$
\text { Formula }(\mathbf{C}) \%=\frac{\mathbf{B}}{\mathbf{A}} * \mathbf{1 0 0}
$$

\subsection{Bioleaching process}

Experiments using fungi and yeast for bioleaching were carried out using 10\% (w/v) autoclaved MSW in $100 \mathrm{~mL}$ of medium. Two bioleaching processes were performed: (i) One-step process: the MSW was incubated with the organism for 15 days; (ii) Two-step process: as decribed by [17]. the organism was pre-cultured for 7 days then the MSW was added and the experiment continued for another 7 days (total experiment time was 15 days). All process carried out with the control MSW with RO water only, a further control was added in which MSW was incubated with microrganisms but no medium was added to see if MSW alone can support fungal growth.

All culture media was autoclaved at $121^{\circ} \mathrm{C}$ for 20 min prior to inoculation and all experiments were carried out in triplicate. Samples $(1 \mathrm{~mL})$ was taken daily using disposable sterilised pipettes and, volume was made up by sterile deionised water if necessary to keep the moisture level stable in the medium. After 15 days, the solid and liquid fraction were separated as previously described.

\subsection{Analytical methods}

2.7.1 Elemental ions: The heavy metal concentration in solutions was analyzed using an Inductively Coupled Plasma Mass Spectrometer (ICP-MS), the percentage of metal extraction (i.e. bioleaching yield) was calculated based on the metal concentration obtained from total digestion using ICP-MS analysis. 
The samples following digestion were analysed using the Inductively Coupled Plasma Mass Spectrometer (ICPMS), which can be used for one of three (multi-element) analytical applications: Trace-element analysis at the ppb $(\mu \mathrm{g} / \mathrm{L})$ level; detector operating in pulse-counting mode but with a mass-dependent cross calibration factor to convert analogue signals. Major element analysis at the $\mathrm{ppm}(\mathrm{mg} / \mathrm{L})$ level; detector operating in analogue mode only, and determination of isotope ratios for individual elements; detector operating in pulse-counting mode only.

2.7.2 Organic acids: Organic acids produced (analysed as citrate, oxalate, gluconate) were determined using a Jasco AS-2055 Intelligent auto sampler (Jasco, Tokyo, Japan) and a Jasco PU-1580 Intelligent pump (Jasco) and RI detectors, using Aminex HPX-87H column with a cation $\mathrm{H}$ guard column (Biorad), mobile phase of $0.0085 \mathrm{M}$ $\mathrm{H}_{2} \mathrm{SO}_{4}$, and flow rate of $0.4 \mathrm{~mL} / \mathrm{min}$ at ambient temperature.

\section{Results}

3.1 MSW characteristics analysis including major and minor elements

The physical and chemical characterisations of the MSW sample were analyzed using standard analytical methods [25]. The preliminary study on the characterisation of MSW, showed that the applied MSW for the experiments was in alkaline condition $\mathrm{pH}=6.8$, the $\mathrm{pH}$ of the substrate has an effect on the solubility of metals during an experiment [28].

\subsection{Presence of elemental ions in MSW}

The elemental composition of three batches of MSW was determined, elements were divided into either major (Table 1) and minor elements (Table 2) based on concentrations present [29]. Elemental analysis of MSW samples revealed that for the major elements $(\mathrm{Na}, \mathrm{Mg}, \mathrm{P}, \mathrm{S}, \mathrm{K}$ and $\mathrm{Ca}$ ) were similar except for $\mathrm{S}$ which was much higher in batch one than in the other two batches. MSW batch one generally had higher levels of the minor elements particularly $\mathrm{Zn}, \mathrm{Cu}, \mathrm{Ni}, \mathrm{Co}, \mathrm{Mn}$ and $\mathrm{Al}$ respectively (Table 2).

\begin{tabular}{|c|c|c|c|c|c|c|}
\hline $\mathrm{Na}^{+}$ & $\mathrm{Mg}^{2+}$ & $\mathbf{P}^{3-}$ & $\mathrm{S}^{-2}$ & $\overline{\mathbf{K}^{+}}$ & $\mathrm{Ca}^{+2}$ & Samples \\
\hline $\begin{array}{c}2509.27 \pm \\
145\end{array}$ & $2722.43 \pm 254$ & $\begin{array}{c}1113.66 \pm \\
151\end{array}$ & $\begin{array}{c}5392.43 \pm \\
299\end{array}$ & $2190.69 \pm 120$ & $\begin{array}{c}25064.74 \pm \\
1550\end{array}$ & First batch \\
\hline $\begin{array}{c}1846.55 \pm \\
219\end{array}$ & $2182.37 \pm 200$ & $\begin{array}{c}1426.67 \pm \\
223\end{array}$ & $\begin{array}{c}2037.69 \pm \\
239\end{array}$ & $1722.23 \pm 231$ & $\begin{array}{c}21075.73 \pm \\
2278\end{array}$ & $\begin{array}{l}\text { Second } \\
\text { batch }\end{array}$ \\
\hline $\begin{array}{c}2177.40 \pm \\
102\end{array}$ & $2385.02 \pm 438$ & $1442.55 \pm 48$ & $\begin{array}{c}2177.92 \pm \\
187\end{array}$ & $1944.97 \pm 105$ & $\begin{array}{c}22168.96 \pm \\
1789\end{array}$ & Third batch \\
\hline $70.09 \pm 8.8$ & $\begin{array}{c}570.11 \pm \\
27.37\end{array}$ & $107.58 \pm 3.02$ & $127.79 \pm 34.2$ & $\begin{array}{c}801.30 \pm \\
38.15\end{array}$ & $1442.80 \pm 92.11$ & Clay \\
\hline
\end{tabular}

Table 1: Major element analysis of the three batches of MSW (mg/kg). 


\begin{tabular}{|c|c|c|c|c|c|c|c|c|c|c|c|}
\hline $\mathbf{B}^{3}$ & $\mathbf{T i}^{3}$ & $\mathbf{A l}^{3+}$ & $\mathbf{V}^{2}$ & $\mathrm{Cr}^{6+}$ & $\mathbf{M n}^{2+}$ & $\mathrm{Fe}^{2+}$ & $\mathrm{Co}^{2}$ & $\mathrm{Ni}^{2+}$ & $\mathrm{Cu}^{2+}$ & $\mathbf{Z n}^{2+}$ & Samples \\
\hline $\begin{array}{r}41.5 \\
6 \pm \\
4.8\end{array}$ & $\begin{array}{c}21.88 \\
\pm 1\end{array}$ & $\begin{array}{c}3120.61 \\
\pm 119\end{array}$ & $\begin{array}{l}23.88 \\
\pm 0.9\end{array}$ & $\begin{array}{l}15.96 \\
\pm 0.7\end{array}$ & $\begin{array}{c}397.73 \\
\pm 3\end{array}$ & $\begin{array}{c}3851.89 \\
\pm 200\end{array}$ & $\begin{array}{l}11.27 \\
\pm 0.6\end{array}$ & $\begin{array}{r}93.47 \\
\pm 28\end{array}$ & $\begin{array}{c}1844.9 \\
5 \pm \\
116\end{array}$ & $\begin{array}{c}612.6 \\
8 \pm \\
43\end{array}$ & 1st batch \\
\hline $\begin{array}{l}6.17 \\
\pm 0.7\end{array}$ & $\begin{array}{c}12.17 \\
\pm 1\end{array}$ & $\begin{array}{c}1876.54 \\
\pm 335\end{array}$ & $\begin{array}{c}26.25 \\
\pm 3\end{array}$ & $\begin{array}{l}25.95 \\
\pm 2.4\end{array}$ & $\begin{array}{c}120.40 \\
\pm 15\end{array}$ & $\begin{array}{c}3258.52 \\
\pm 548\end{array}$ & $\begin{array}{c}1.83 \pm \\
0.23\end{array}$ & $\begin{array}{c}12.69 \\
\pm 2\end{array}$ & $\begin{array}{c}122.08 \\
\pm 63\end{array}$ & $\begin{array}{c}346.8 \\
4 \pm \\
99\end{array}$ & 2nd batch \\
\hline $\begin{array}{r}6.96 \\
\pm 0.3\end{array}$ & $\begin{array}{c}12.50 \\
\pm 1\end{array}$ & $\begin{array}{c}1954.41 \\
\pm 133\end{array}$ & $\begin{array}{c}26.71 \\
\pm 1\end{array}$ & $\begin{array}{l}26.88 \\
\pm 2.3\end{array}$ & $\begin{array}{c}137.24 \\
\pm 5\end{array}$ & $\begin{array}{c}2817.18 \\
\pm 274\end{array}$ & $\begin{array}{c}1.83 \pm \\
0.08\end{array}$ & $\begin{array}{c}12.37 \\
\pm 1\end{array}$ & $\begin{array}{c}70.37 \\
\pm 5\end{array}$ & $\begin{array}{c}388.9 \\
3 \pm \\
117\end{array}$ & 3rd batch \\
\hline $\begin{array}{c}0.03 \\
\pm \\
0.00 \\
5\end{array}$ & $\begin{array}{l}3.51 \\
\pm 0.2\end{array}$ & $\begin{array}{c}1988.89 \\
\pm 80.3\end{array}$ & $\begin{array}{r}22.10 \\
\pm 1.3\end{array}$ & $\begin{array}{l}11.99 \\
\pm 0.5\end{array}$ & $\begin{array}{c}157.84 \\
\pm 6.1\end{array}$ & $\begin{array}{l}11685.5 \\
2 \pm 550\end{array}$ & $\begin{array}{r}5.089 \\
\pm 0.15\end{array}$ & $\begin{array}{l}11.80 \\
\pm 0.4\end{array}$ & $\begin{array}{c}7.70 \pm \\
1.2\end{array}$ & $\begin{array}{c}13.07 \\
\pm \\
2.54\end{array}$ & Clay \\
\hline $\mathrm{As}^{3-}$ & $\mathrm{Se}^{3-}$ & $\mathbf{R b}^{3-}$ & $\mathrm{Sr}^{2-}$ & $\mathbf{M o}^{3+}$ & $\mathbf{A g}^{+}$ & $\mathrm{Cd}^{2+}$ & $\mathrm{Cs}^{+}$ & $\mathbf{B a}^{2+}$ & $\mathbf{P b}^{+}$ & $\mathbf{U}^{4+}$ & Samples \\
\hline $\begin{array}{r}2.98 \\
\pm 0.4\end{array}$ & $\begin{array}{c}0.13 \\
\pm \\
0.02\end{array}$ & $\begin{array}{c}2.32 \pm \\
0.14\end{array}$ & $\begin{array}{c}63.41 \\
\pm 7\end{array}$ & $\begin{array}{c}3.39 \\
\pm \\
0.08\end{array}$ & $\begin{array}{c}3.15 \pm \\
0.38\end{array}$ & $\begin{array}{c}33.92 \pm \\
2\end{array}$ & $\begin{array}{l}0.15 \pm \\
0.012\end{array}$ & $\begin{array}{c}291.2 \\
2 \pm \\
24\end{array}$ & $\begin{array}{c}161.19 \\
\pm 9\end{array}$ & $\begin{array}{c}0.23 \\
\pm \\
0.018\end{array}$ & 1st batch \\
\hline $\begin{array}{l}1.57 \\
\pm 0.1\end{array}$ & $\begin{array}{c}0.15 \\
\pm \\
.028\end{array}$ & $\begin{array}{c}1.74 \pm \\
0.25\end{array}$ & $\begin{array}{l}44.71 \\
\pm 6\end{array}$ & $\begin{array}{c}1.15 \\
\pm \\
0.14\end{array}$ & $\begin{array}{c}0.48 \pm \\
0.06\end{array}$ & $\begin{array}{c}1.35 \pm \\
0.08\end{array}$ & $\begin{array}{c}0.12 \pm \\
0.02\end{array}$ & $\begin{array}{r}62.93 \\
\pm 12\end{array}$ & $\begin{array}{c}123.66 \\
\pm 25\end{array}$ & $\begin{array}{c}0.16 \\
\pm \\
0.025\end{array}$ & 2nd batch \\
\hline $\begin{array}{r}1.59 \\
\pm 0.2\end{array}$ & $\begin{array}{c}0.14 \\
\pm \\
0.021\end{array}$ & $\begin{array}{c}1.92 \pm \\
0.14\end{array}$ & $\begin{array}{c}45.92 \\
\pm 3\end{array}$ & $\begin{array}{c}1.22 \\
\pm \\
0.17\end{array}$ & $\begin{array}{c}0.56 \pm \\
0.05\end{array}$ & $\begin{array}{c}2.64 \pm \\
0.6\end{array}$ & $\begin{array}{l}0.12 \pm \\
0.007\end{array}$ & $\begin{array}{c}61.97 \\
\pm 5\end{array}$ & $\begin{array}{c}123.37 \\
\pm 13\end{array}$ & $\begin{array}{c}0.15 \\
\pm \\
0.011\end{array}$ & 3rd batch \\
\hline $\begin{array}{c}1.45 \\
\pm \\
0.17\end{array}$ & $\begin{array}{c}0.18 \\
\pm \\
0.015\end{array}$ & $\begin{array}{c}6.078 \pm \\
0.3\end{array}$ & $\begin{array}{r}22.33 \\
\pm 1.18\end{array}$ & $\begin{array}{c}0.053 \\
\pm \\
0.031\end{array}$ & $\begin{array}{c}0.050 \\
\pm \\
0.033\end{array}$ & $\begin{array}{c}0.058 \pm \\
0.03\end{array}$ & $\begin{array}{c}1.87 \pm \\
0.2\end{array}$ & $\begin{array}{l}54.03 \\
\pm 2.2\end{array}$ & $\begin{array}{c}6.32 \pm \\
1.2\end{array}$ & $\begin{array}{c}0.68 \\
\pm \\
0.02\end{array}$ & Clay \\
\hline
\end{tabular}

Table 2: Minor element analysis of the three batches of MSW (mg/kg).

\subsection{Presence of elemental ions in MSW samples incubated in clay medium}

Clay was applied as a medium in order to remove elements from MSW; following incubation in clay based medium the elemental concentrations were determined in Tables 1 and 2. 


\subsection{Leaching metals from MSW using various media and conditions}

The efficiency of washing MSW with RO water, shaking and incubation for 1, 7 and 15 days was determined, the results revealed that washing decreased the concentration of metals in the solid residue. However, concentrations of some metals, in particular $\mathrm{Cu}$ and $\mathrm{Zn}$ were still high. Washing MSW with $\mathrm{RO}$ water reduced $\mathrm{Ni}, \mathrm{Cd}$ and $\mathrm{Cr}$, as shown in Figure 1. Thus further experiments were carried out in an attempt to improve the leaching of these metals.

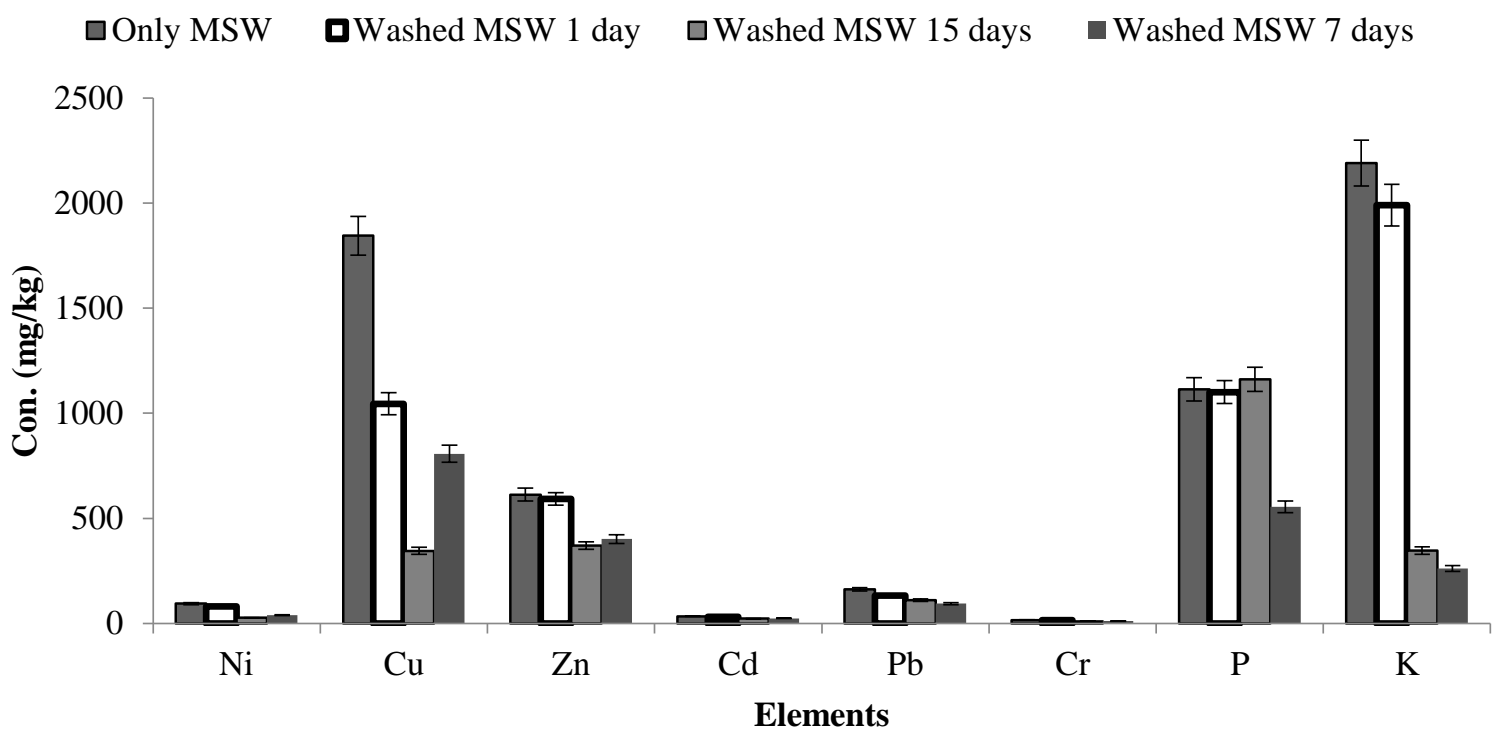

Figure 1: Effect of washing with RO water on the concentration of elements in MSW. MSW was incubated with water for 1 and 7 and 15 days, the solid residue was collected, dried and elemental composition determined. This was compared to the control (unwashed MSW).

\subsection{Chemical leaching of MSW using organic and non-organic acids}

To compare the effect of chemical leaching of MSW, a study was carried out using sulphuric, oxalic and gluconic acids to leach elements from MSW. MSW was incubated with the organic acid for either 7 or 15 days and the elemental composition of the dried residue determined. This was compared to a control which was incubated in RO water. For ease of comparison, the amount of each element remaining in the solid residue has been expressed as $\%$ of that in the original unwashed MSW. Overall for 7 and 15 days, addition of $\mathrm{H}_{2} \mathrm{SO}_{4}$ gave the best performance (lowest retained yield $\%$ in a solid residue) (Figure 2).

To compare effects of organic acid for leaching MSW, results revealed that addition of gluconic acid correlated with better performance when compared with addition of other organic acids in terms of removing elements from the solid fraction of MSW. These results revealed that using organic acid did not improve the removal of elements when compared with the control (using only RO water with MSW). 
- 7 days Sulfuric acid

- 7 days water

- 15 days Gluconic acid
- 7 days Oxalic acid

- 15 days Sulfuric acid

$\square 15$ days water

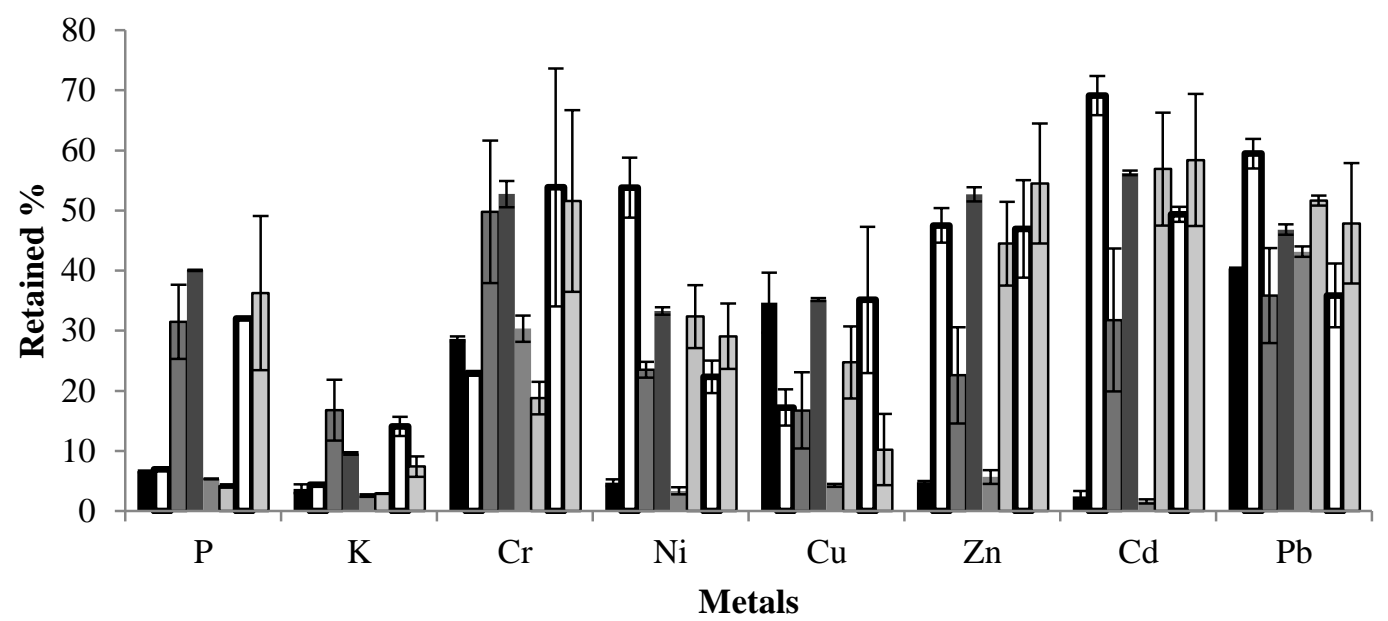

Figure 2: Effect of incubating MSW in either water or acids on elemental composition of MSW. MSW was incubated with water or acids for 7 and 15days. The solid residue was dried and elemental composition determined.

Results are expressed as\% remaining compared to original MSW.

ANOVA analysis compared the three different acid mediums in terms of removing 8 metals from MSW after either 7 or 15 days incubation. ANOVA analysis revealed that use of sulphuric acid for 7 and 15 days correlated with better retained\% yield than incubation with other organic acids. There was no significant difference between 7 and 15 days incubation in terms of presence of any metal in the MSW (Table 3).

\begin{tabular}{|c|c|c|c|c|c|c|c|c|}
\hline \multicolumn{9}{|c|}{ Treatments mean solid yield value \% } \\
\hline & \multicolumn{3}{|c|}{7 days } & \multicolumn{3}{|c|}{15 days } & \multicolumn{2}{|c|}{$\mathrm{P}>$ value } \\
\hline $\begin{array}{c}\text { Metal } \\
\text { s }\end{array}$ & $\begin{array}{c}\text { Sulphuric } \\
\text { acid }\end{array}$ & $\begin{array}{c}\text { Oxalic } \\
\text { acid }\end{array}$ & $\begin{array}{c}\text { Gluconic } \\
\text { acid }\end{array}$ & $\begin{array}{c}\text { Sulphuric } \\
\text { acid }\end{array}$ & Oxalic acid & $\begin{array}{c}\text { Gluconic } \\
\text { acid }\end{array}$ & $\begin{array}{c}\text { A } \\
\text { factor } \\
\text { (Acids) }\end{array}$ & $\begin{array}{c}B \\
\text { factor } \\
\text { (time ) }\end{array}$ \\
\hline $\mathbf{P}$ & $\begin{array}{c}6.59 \pm \\
0.17\end{array}$ & $\begin{array}{c}6.97 \pm \\
0.08\end{array}$ & $\begin{array}{c}31.48 \pm \\
6.14\end{array}$ & $\begin{array}{l}5.35 \pm \\
0.085\end{array}$ & $4.17 \pm 0.27$ & $\begin{array}{c}32.018 \pm \\
0.089\end{array}$ & 0.001 & $0.82 *$ \\
\hline $\mathbf{K}$ & $3.72 \pm 0.7$ & $\begin{array}{c}4.377 \pm \\
0.04\end{array}$ & $16.77 \pm 5$ & $2.59 \pm 0.2$ & $2.90 \pm 0.05$ & $14.09 \pm 1.6$ & 0.0001 & $0.305^{*}$ \\
\hline $\mathrm{Cr}$ & $\begin{array}{c}28.7 \pm \\
0.42\end{array}$ & $22.9 \pm 0.3$ & $\begin{array}{c}49.8 \pm \\
11.84\end{array}$ & $30.3 \pm 2.2$ & $18.8 \pm 2.6$ & $53.9 \pm 19$ & 0.0004 & $0.345^{*}$ \\
\hline $\mathbf{N i}$ & $\begin{array}{c}4.75 \pm \\
0.55\end{array}$ & $53.80 \pm 20$ & $\begin{array}{c}23.511 \pm \\
1.3\end{array}$ & $3.36 \pm 0.6$ & $32.35 \pm 5.2$ & $22.34 \pm 2.7$ & 0.012 & $0.862 *$ \\
\hline $\mathbf{C u}$ & $\begin{array}{c}34.67 \pm \\
3.5\end{array}$ & $\begin{array}{c}17.23 \pm \\
2.3\end{array}$ & $16.74 \pm 6.3$ & $4.28 \pm 0.2$ & $24.75 \pm 5.2$ & $35.12 \pm 3.2$ & $0.97 *$ & $0.783 *$ \\
\hline
\end{tabular}




\begin{tabular}{|c|c|c|c|c|c|c|c|c|}
\hline $\mathbf{Z n}$ & $4.8 \pm 0.2$ & $47.5 \pm 2.8$ & $22.6 \pm 4.3$ & $5.7 \pm 1.15$ & $44.5 \pm 6.9$ & $46.9 \pm 9.3$ & 0.0001 & $0.375^{*}$ \\
\hline $\mathbf{C d}$ & $2.5 \pm 0.8$ & $69.1 \pm 3.2$ & $31.8 \pm 11.2$ & $1.6 \pm 0.3$ & $56.9 \pm 9.3$ & $49.4 \pm 1.2$ & 0.0001 & $0.59^{*}$ \\
\hline $\mathbf{P b}$ & $\begin{array}{c}40.4 \pm \\
0.08\end{array}$ & $59.5 \pm 2.4$ & $35.9 \pm 7.9$ & $43.1 \pm 0.8$ & $51.6 \pm 0.83$ & $35.9 \pm 5.3$ & 0.006 & $0.98^{*}$ \\
\hline & 15.7 & 35.1 & 28.5 & 5.02 & 14.5 & 13.6 & & \\
\hline
\end{tabular}

Table 3: ANOVA table for the effect of three organic and inorganic chemicals on amount retained in the solid fraction at two time points.

\subsection{Comparison of fungal strains for the bioleaching of metals from MSW using one and two-way methods}

The next set of experiments explored the application of bioleaching for the improvement of the elemental composition of MSW. For this experiment, three fungal strains (A. niger, T. reesei and A. terrus) were used. Spores of fungi were inoculated into media whose $\mathrm{pH}$ had been adjusted to $\mathrm{pH}$ 5.5. Bioleaching was assessed using either a one step method (mixing MSW with the medium and strain at the same time) or a two step method (mixing medium with strain for 7 days then transfering to the autoclaved MSW). Following 15 days incubation, the solid phases were collected and elemental analysis carried out.

Controls were as mentioned previously along with a control where mixing MSW with microorganism in the absent of nutrients or media was added, the aim being to see if these organisms can grow without extra glucose in the medium. Results are again presented as\% of original amount retained in the solid residue. Comparison of the retained (\%) of metals within the MSW solid residue revealed that the one-way method was the best and that $A$. niger was the most efficient microorganism in terms of leaching ability (Figure 3). In terms of leaching of elements from MSW, $\mathrm{K}$ and $\mathrm{Cu}$ showed lowest retained\% yield when compared with other elements (Figure 3).

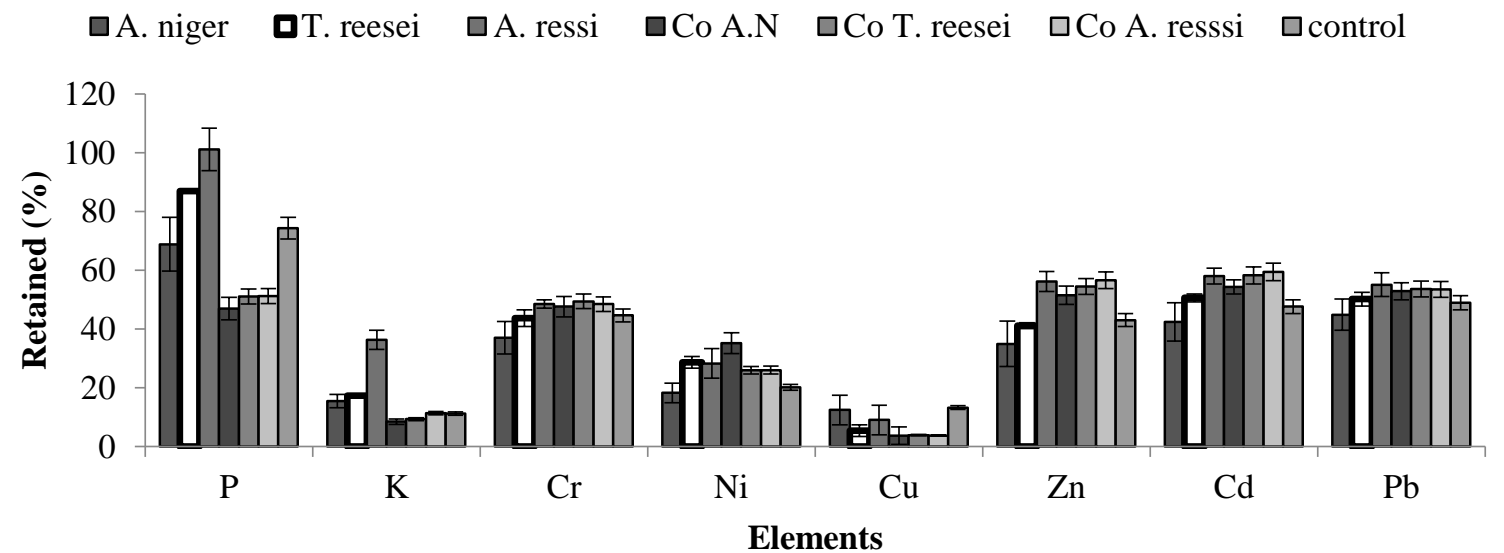

Figure 3: Effect of bioleaching on MSW elemental composition using three fungal strains. Retained yield (\%) of elements in a solid residue of MSW using one-way method and three fungal strains in a present of artificial medium at pH 5.5 at 15 days' time point. $\mathrm{Co}=$ control (no nutrient addition to the medium, only MSW and microorganisms in a RO water). 
Data from the bioleaching experiments for the 8 metals with the retained yield $\%$ using three fungal strains was analysed using Design Expert and ANOVA to calculate the relationship between factors (fungi) for each elements (Table 4).

\begin{tabular}{|c|c|c|c|c|c|}
\hline & \multicolumn{4}{|c|}{ Treatments mean value } & \multirow{2}{*}{$\begin{array}{c}\mathrm{P}>\text { value } \\
\text { A factor (Fungi) }\end{array}$} \\
\hline Metals & A. niger & T. reesei & A. terreus & water & \\
\hline $\mathbf{P}$ & $68.84 \pm 9.15$ & $86.95 \pm 0.1$ & $101.13 \pm 7.2$ & $74.33 \pm 4.25$ & 0.039 \\
\hline $\mathbf{K}$ & $15.50 \pm 2.2$ & $17.34 \pm 0.18$ & $36.34 \pm 3.2$ & $11.27 \pm 2.51$ & 0.049 \\
\hline $\mathrm{Cr}$ & $43.31 \pm 5.8$ & $54.049 \pm 3.5$ & $65.99 \pm 0.4$ & $44.66 \pm 6.54$ & $0.114^{*}$ \\
\hline $\mathbf{N i}$ & $26.34 \pm 6.2$ & $42.0 \pm 1.5$ & $45.8 \pm 2.5$ & $20.13 \pm 5.25$ & $0.108^{*}$ \\
\hline $\mathbf{C u}$ & $12.47 \pm 9.4$ & $5.428 \pm 0.03$ & $9.09 \pm 7.1$ & $13.31 \pm 4.21$ & $0.634 *$ \\
\hline $\mathbf{Z n}$ & $35.0 \pm 7.7$ & $41.18 \pm 1$ & $56.26 \pm 3.39$ & $43.08 \pm 2.21$ & 0.047 \\
\hline $\mathbf{C d}$ & $43.263 \pm 2.4$ & $61.12 \pm 3.2$ & $85.19 \pm 0.1$ & $47.64 \pm 8.25$ & $0.074 *$ \\
\hline $\mathbf{P b}$ & $44.90 \pm 5.3$ & $50.19 \pm 2.3$ & $55.12 \pm 4.00$ & $48.96 \pm 9.25$ & $0.184 *$ \\
\hline- & 34.32 & 40.52 & 49.1 & 37.9 & - \\
\hline
\end{tabular}

Table 4: ANOVA table represents the amount of retained elements in the solid fraction of MSW using one-way method and three fungal strains in a present of artificial medium at $\mathrm{pH} 5.5$ for the 15 days duration.

\subsection{Effect of $\mathrm{pH}$ and medium compositions on bioleaching elements from MSW}

From the previous experiment, A. niger using a one way method was selected as the best condition. The $\mathrm{pH}$ of artificial, clay and sorghum media was adjusted to either $\mathrm{pH} 5.5$ or 2.5 and inoculated with A. niger, samples were taken after 4, 6, 8, 10,12, and 15 days to determine the concentrations of elements in the liquid and solid phases as described above. Controls containing no fungal inoculum were also included and samples taken out at the same time point for comparison. ANOVA analysis revealed that incubation with a clay based media resulted in the lowest retention (best performance) when compared to the other media for all metals analysed (Figure 4). Clay medium showed better performance in terms of lowest retention yield (best performance) but results were not an improvement on the control (washed by water). These mediums had no significant difference on leachate of elements from MSW (Table 5).

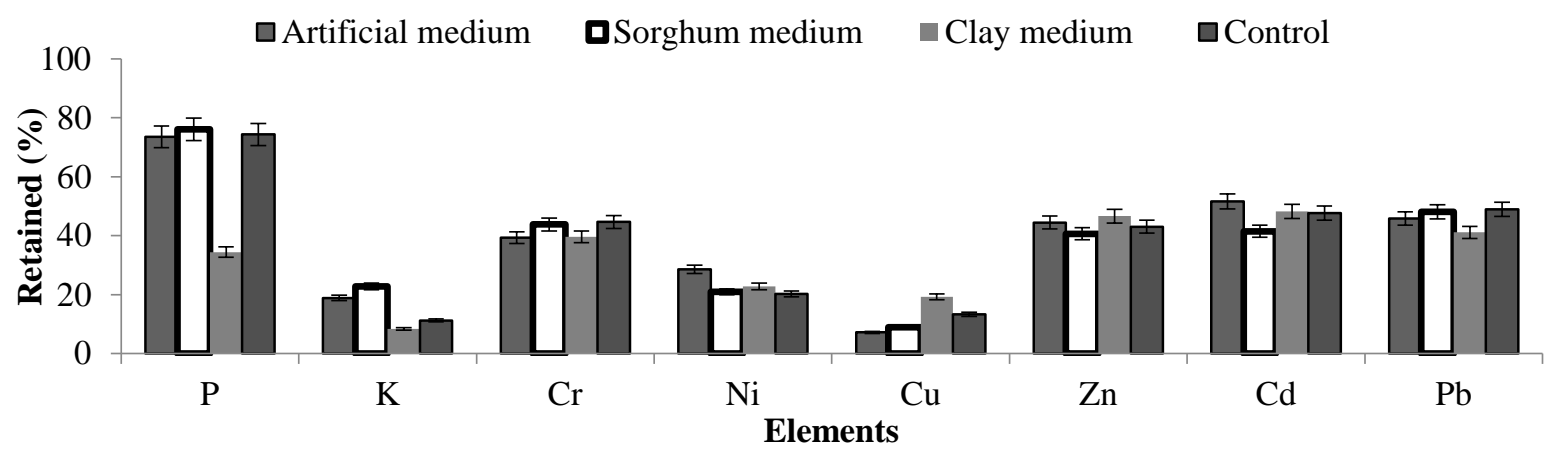

Figure 4: Amount of retained elements in the solid residue was assessed at pH 5.5 and the impact of three different media- artificial, clay and sorghum medium using A. niger. 


\begin{tabular}{|c|c|c|c|c|c|}
\hline & \multicolumn{4}{|c|}{ Treatments mean value solid yield \% } & \multirow{2}{*}{$\begin{array}{c}\text { P> value } \\
\text { A factor (medium) }\end{array}$} \\
\hline Metals & Artificial Med. & Sorghum Med. & Clay Med. & water & \\
\hline $\mathbf{P}$ & $73.51 \pm 3.2$ & $76.04 \pm 9.3$ & $34.45 \pm 1.6$ & $74.33 \pm 4.25$ & $0.110^{*}$ \\
\hline $\mathbf{K}$ & $18.90 \pm 1.2$ & $22.82 \pm 3.8$ & $8.42 \pm 1.1$ & $11.27 \pm 2.51$ & $0.1519 *$ \\
\hline $\mathbf{C r}$ & $39.33 \pm 0.97$ & $43.81 \pm 1.84$ & $39.68 \pm 2.8$ & $44.66 \pm 6.54$ & $0.338 *$ \\
\hline $\mathbf{N i}$ & $28.58 \pm 6.6$ & $20.95 \pm 3$ & $22.81 \pm 1.9$ & $20.13 \pm 5.25$ & $0.188^{*}$ \\
\hline $\mathbf{C u}$ & $7.22 \pm 1.2$ & $8.96 \pm 2.6$ & $19.22 \pm 1.1$ & $13.31 \pm 4.21$ & $0.272 *$ \\
\hline $\mathbf{Z n}$ & $44.49 \pm 5.2$ & $40.67 \pm 2.4$ & $46.65 \pm 0.3$ & $43.08 \pm 2.21$ & $0.356^{*}$ \\
\hline Cd & $51.63 \pm 6.8$ & $41.52 \pm 1.33$ & $48.27 \pm 0.4$ & $47.64 \pm 8.25$ & $0.120^{*}$ \\
\hline $\mathbf{P b}$ & $45.80 \pm 0.76$ & $48.06 \pm 0.54$ & $41.12 \pm 0.35$ & $48.96 \pm 9.25$ & $0.1509 *$ \\
\hline & 38.68 & 37.85 & 32.58 & 37.9 & \\
\hline
\end{tabular}

Table 5: P-value of analysis of variance (ANOVA) table of the amount of retained elements in the solid fraction in a MSW using three mediums and A. niger at starting $\mathrm{pH}$ 5.5.

Generally, more acidic conditions ( $\mathrm{pH} 2.5$ ) helped to dissolve elements easier than at $\mathrm{pH} 5.5$, so bioleaching at this $\mathrm{pH}$ was assessed, results revealed that incubation with a sorghum based medium had the lowest retained elemental ions (Table 5) when compared with the other mediums (Figure 5).

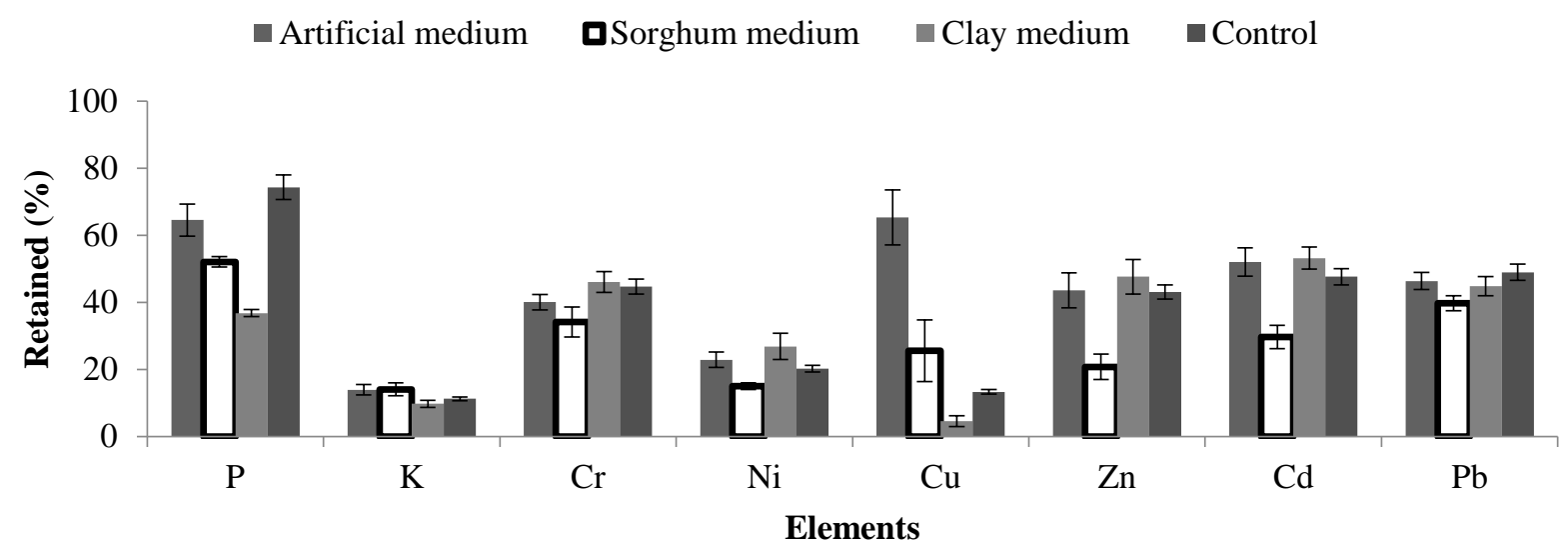

Figure 5: Amount of retained elements in the solid fraction of MSW using A. niger at $\mathrm{pH} 2.5$ and three mediums (Artificial, Sorghum and Clay medium) compared with (washed MSW).

ANOVA analysis on the presence of 8 elements retained in the solid residue, using three different media revealed that there was significant different between mediums. The results showed that sorghum media was significantly $(\mathrm{p}=0.0048)$ better when compared with other mediums (Table 6). 


\begin{tabular}{|l|l|l|l|l|l|}
\hline \multicolumn{4}{|l|}{ Treatments mean value\% } & & \multirow{2}{*}{ P> value } \\
\hline Metals & Artificial Med. & Sorghum Med. & Clay Med. & water & A factor (medium) \\
\hline P & $64.6 \pm 4.8$ & $52.1 \pm 1.5$ & $36.8 \pm 1.08$ & $74.33 \pm 4.25$ & 0.001 \\
\hline K & $13.93 \pm 1.52$ & $14.04 \pm 1.9$ & $9.74 \pm 1.06$ & $11.27 \pm 2.51$ & 0.048 \\
\hline Cr & $40.1 \pm 2.3$ & $34.1 \pm 4.5$ & $46.1 \pm 3.1$ & $44.66 \pm 6.54$ & 0.0015 \\
\hline Ni & $22.89 \pm 2.2$ & $15.01 \pm 1.03$ & $26.85 \pm 3.8$ & $20.13 \pm 5.25$ & 0.007 \\
\hline Cu & $65.28 \pm 20$ & $25.53 \pm 17.05$ & $4.54 \pm 1.6$ & $13.31 \pm 4.21$ & 0.45 \\
\hline Zn & $43.59 \pm 5.17$ & $20.78 \pm 3.7$ & $47.63 \pm 5.11$ & $43.08 \pm 2.21$ & 0.001 \\
\hline Cd & $52 \pm 4.2$ & $29.6 \pm 3.49$ & $53.2 \pm 3.2$ & $47.64 \pm 8.25$ & 0.001 \\
\hline Pb & $46.3 \pm 2.5$ & $39.7 \pm 2.2$ & $44.8 \pm 2.8$ & $48.96 \pm 9.25$ & 0.0004 \\
\hline & 43.5 & 28.8 & 33.7 & 37.9 & \\
\hline
\end{tabular}

Table 6: ANOVA table for the amount of retained elements in the solid fraction of MSW using three mediums and A. niger at starting $\mathrm{pH} 2.5$.

In order to compare bioleaching at $\mathrm{pH} 2.5$ or $\mathrm{pH} 5.5$, average total elements retained (\% yield) from the solid fraction was compared, in general bioleaching was better at $\mathrm{pH} 2.5$ when compared with $\mathrm{pH}$ 5.5. The best retained yield was $28.9 \%$ using sorghum media at $\mathrm{pH} 2.5$ comparing with washed water retained yield was $33.28 \%$ (Figure $6)$.

\section{$\square \mathrm{pH} 2.5$ 口pH5.5}

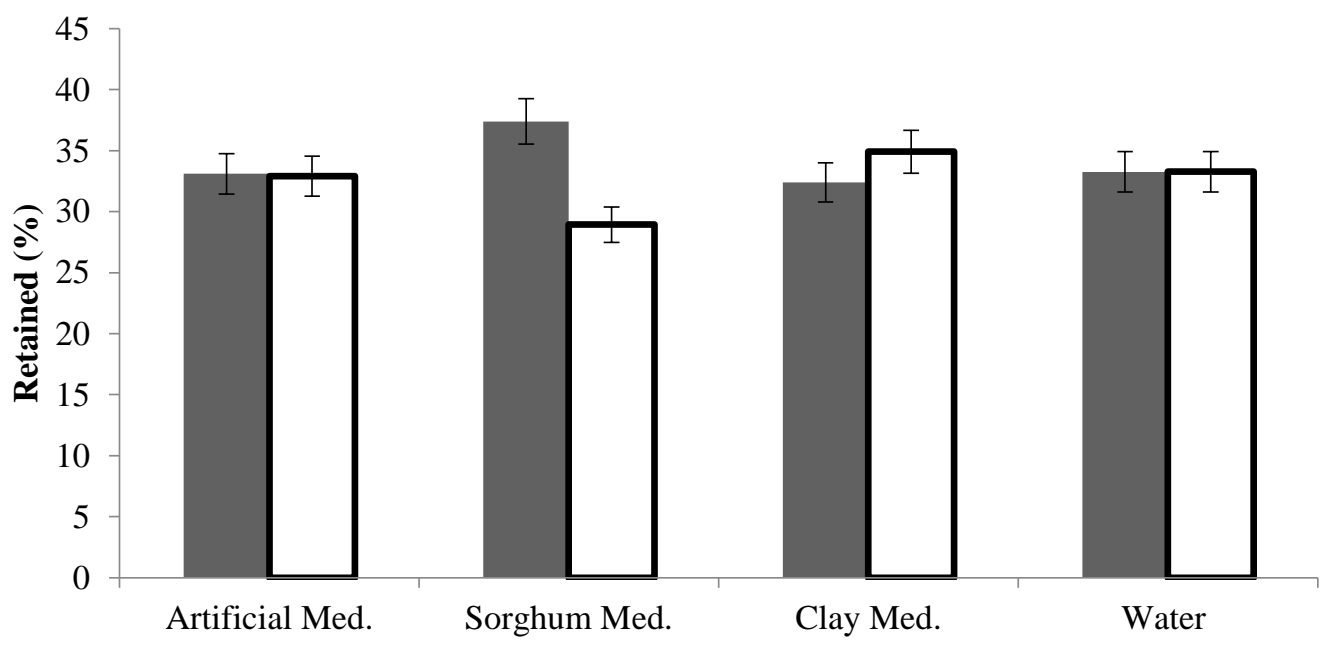

Mediums

Figure 6: Comparing amount of retained yield\% in the solid fraction of total elements in MSW with a starting pH of either 2.5 or 5.5 and three media using A. nger fungi. 
3.8 Organic acid production as a by-product using fungi and different media

Fungi produce organic acids such as gluconic, oxalic or citric acids as part of the bioleaching mechanism. These acids can be used for chemical leaching of MSW, or indeed represent byproducts of the process. Use of these acids could decrease the cost of chemical leaching and at the same time add value to the liquid fraction. Thus in addition to bioleaching, the production of organic acids was also assessed in these experiments.

A bioleaching experiment was carried out using a starting $\mathrm{pH}$ of 5.5, with artificial, clay and sorghum and addition of A. niger using a one way method. The production of organic acids -gluconic, oxalic and citric was determined over 15 days. The results are shown in Figure 7. A. niger was shown to produce all three organic acids, with gluconic acid detected at the highest concentrations. Results revealed that addition of either sorghum or artificial medium resulted in increased organic acid production. Gluconic acid production was initially highest on artificial medium but decreased after the first few days. Production on sorghum medium was also initially high and again declined with time. There was little production observed with the clay medium. However, citric acid production was initially low in all media tested but increased transiently in the sorghum media after about 10 days. Oxalic acid production was only observed in the sorghum medium and again this was transient. Acid production in all three cases was very low.
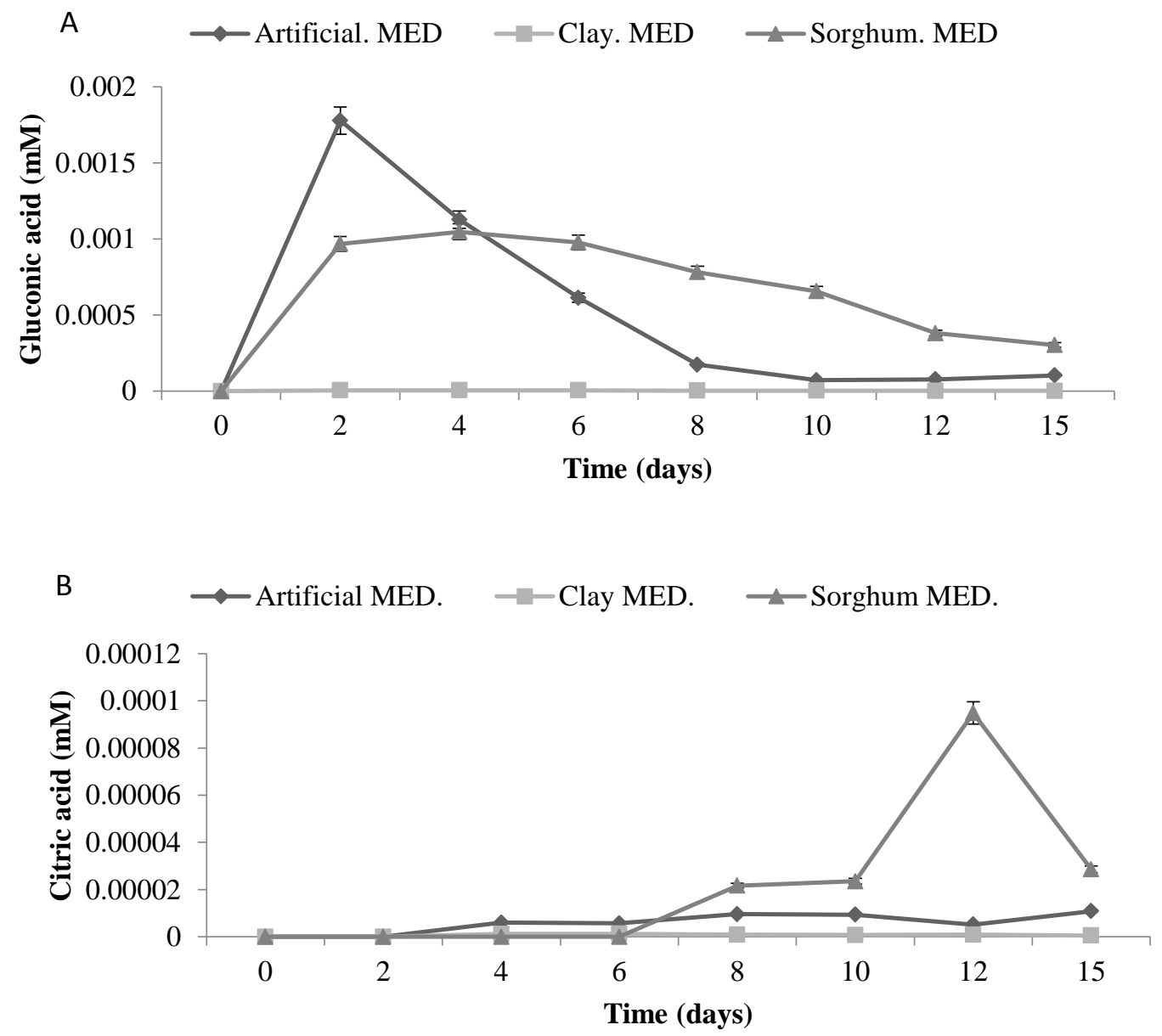


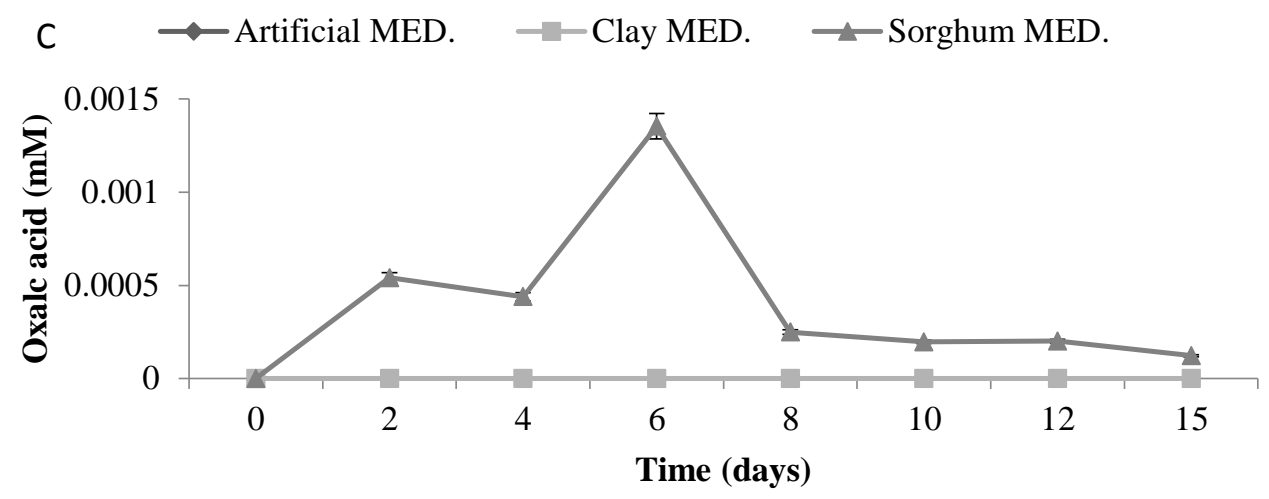

Figure 7: Organic acid production during bioleaching of MSW. MSW was incubated at a starting pH of 5.5, using three media inoculated with A. niger to determine the production of three organic acids (A) Gluconic acid (B) Citric acid and (C) Oxalic acid, Data represented as a triplicate values (Med = Medium).

The experiment was repeated using a starting $\mathrm{pH}$ of 2.5. Assays with a starting $\mathrm{pH}$ of 2.5 required the addition of 25 $\mathrm{mL}$ sterile RO water at day 9 to keep the moisture levels stable in the flasks, results revealed that gluconic acid production profiles were similar to those seen at $\mathrm{pH}$ 5.5. Production of the other two acids was very low (Figure 8).
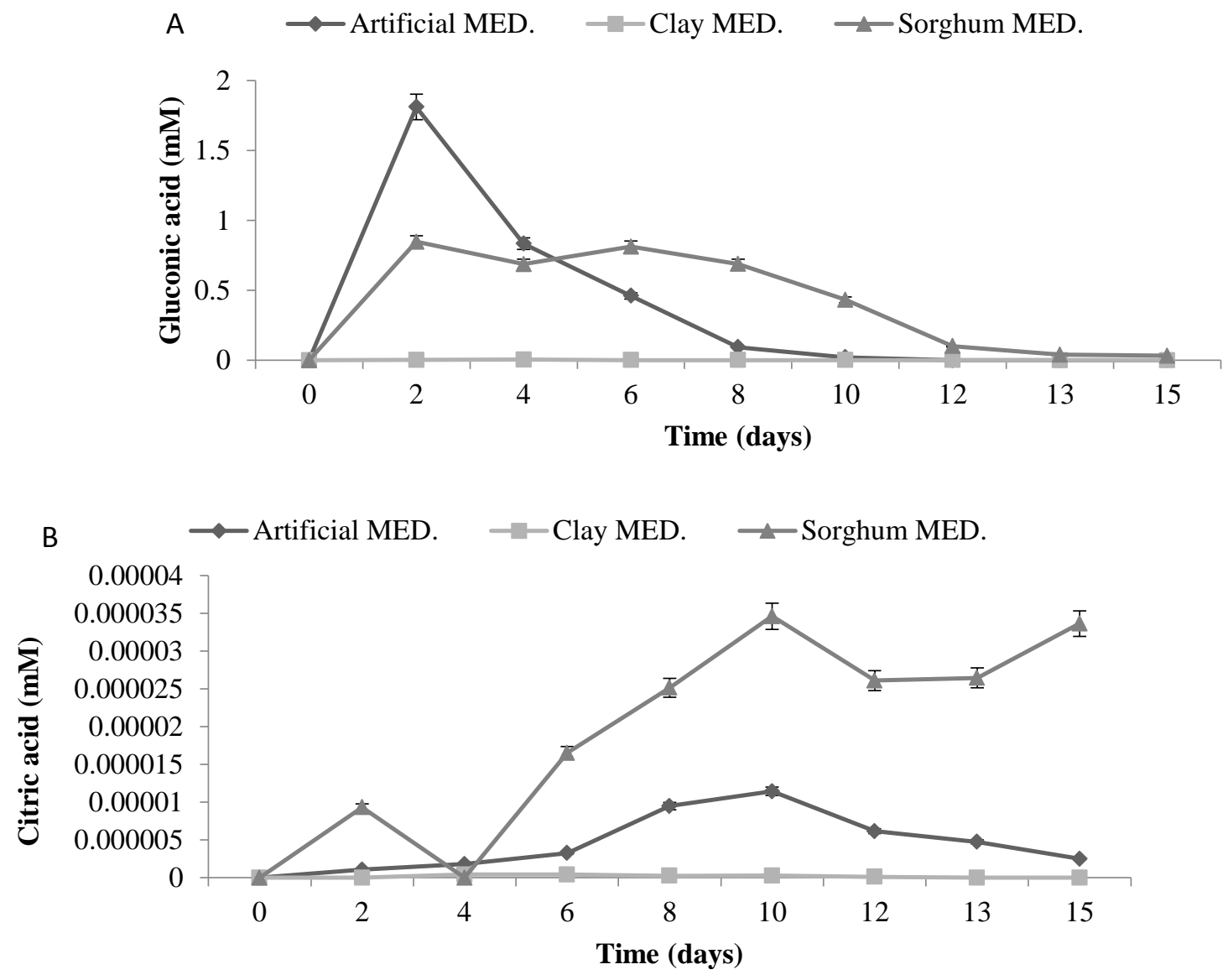


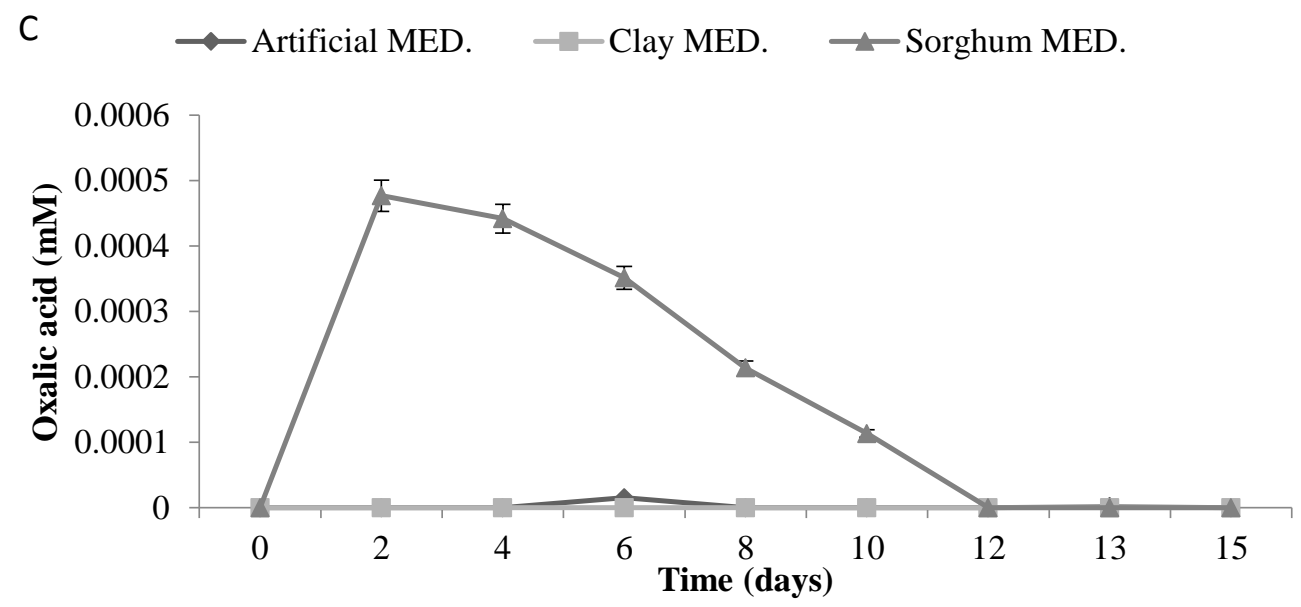

Figure 8: Organic acid production using pH 2.5 and three mediums over time., using three mediums inoculated (A. niger) to determine three organic acids (A) Gluconic acid (B) Citric acid and (C) Oxalic acid. Data represented as a triplicate values.

\section{Discussion}

The main sources of heavy metal ions in MSW are from batteries ( $\mathrm{Ni}, \mathrm{Zn}$, and $\mathrm{Cd}$ ); and reasons for their retention are poor availability of recycling facilities for hazardous wastes and poor public attitudes to waste management [30, 31]. In addition, other materials such as paints, electronics, ceramics, plastics and inks/ dyes can all contribute to the heavy metal presence in MSW [30, 32]. Generally, paper fractions contain the highest concentration of these metals [33]. However, information about quantity and sources of hazardous metals in MSW are lacking [34, 35]. Elemental ions can be classified into three classes based on their biological function and effects: (1) essential ions ( $\mathrm{Na}, \mathrm{K}, \mathrm{Mg}$, $\mathrm{Ca}, \mathrm{V}, \mathrm{Mn}, \mathrm{Fe}, \mathrm{Co}, \mathrm{Ni}, \mathrm{Cu}, \mathrm{Zn}, \mathrm{Moand} \mathrm{W}$ ); (2) toxic metal ions (Ag, Cd, Sn, Au, Hg, Ti, Pb, Al and metalloids, Ge, $\mathrm{As}, \mathrm{Sb}$, and $\mathrm{Se}$ ) and (3) nonessential, nontoxic metals ( $\mathrm{Rb}, \mathrm{Cs}$, and $\mathrm{Sr}$ ) [36]. Heavy metals can also be classified according to their volatility, when MSW leaves the furnace and passes through the heat recovery boiler, volatile metals such as lead and cadmium can condense and attach to the substrate, highly volatile metals such as mercury and arsenic and can be present in the fumes [37], So temperature, residence time and presence of reactive compounds can have significant effects on heavy metal condensation and release from and to MSW [38]. In this study, major and minor elements were determined. Concentrations of metal ions in the first batch were higher than those observed in the other MSW batches. In the first MSW sample, the metal ion found in the highest concentration found was $\mathrm{Ca}(25064.75 \mathrm{mg} / \mathrm{kg})$. Presence of calcium was probably due to the formation of metal oxides from the lime spray treatment during the incineration process. Sulphur was recorded as the second highest major element $(5392.43 \mathrm{mg} / \mathrm{kg}$ ) possibly due to sulphur being released due to the high temperatures and burnout during the incineration process [39]. In comparison, presence of Ca content in the first MSW sample was higher than has been detected in previously published paper [27, 40,41], but lower than other published papers [17, 39, 42, 43]. While, for $\mathrm{K}$ content the composition content was higher than other two batches, and lower than some of the data published previously [17, 39, 42, 43]. 
Other elemental ions were present at less than $(>10,000 \mathrm{mg} / \mathrm{kg}$ ) including $\mathrm{K}, \mathrm{Mg}, \mathrm{Na}, \mathrm{S}$ and $\mathrm{P}$. It was noted that most of these constituents are volatile elements which are released due to the high temperatures and burnout during the incineration process [39].

The levels of the major components found in this present study were higher when compared with some other studies as shown in Table 7. This is probably due to the high concentrations of salty food waste and plastic material in the MSW used in this study, the major source of chloride in $\mathrm{MSW}$ is $\mathrm{NaCl}$ and $\mathrm{KCl}$, the concentrations of chlorides in these concurs with published reports [41]. In addition, incinerated MSW contains soluble salts and mineralogical phases such as anhydrite (CaSO4), Quartiz (SiO2), gehlenite (Ca2Al (AlSi)O7), hematite (Fw2 O3) and portlandite $(\mathrm{Ca}(\mathrm{OH}) 2)[44]$.

\begin{tabular}{|c|c|c|c|c|c|l|}
\hline $\mathbf{N a}^{+}$ & $\mathbf{M g}^{2+}$ & $\mathbf{P}^{3-}$ & $\mathbf{S}^{-2}$ & $\mathbf{C a}^{+2}$ & Reference \\
\hline 2509.3 & 2722.4 & 1113.7 & 5392.4 & 2190.7 & 25064.7 & First batch \\
\hline 1846.6 & 2182.4 & 1426.7 & 2037.7 & 1722.2 & 21075.7 & Second batch \\
\hline 2177.4 & 2385.0 & 1442.6 & 2177.9 & 1945.0 & 22169.0 & Third batch \\
\hline$*$ & $*$ & 3500.0 & 6200.0 & 16700.0 & 205000.0 & {$[42]$} \\
\hline$*$ & $*$ & $*$ & $*$ & $*$ & 114.3 & {$[40]$} \\
\hline$*$ & 10820.0 & $*$ & $*$ & 23020.0 & 258000.0 & {$[17]$} \\
\hline$*$ & 9110.0 & $*$ & $*$ & 11500.0 & 404000.0 & {$[43]$} \\
\hline 23.1 & 2.0 & 1.7 & 5.7 & 13.6 & 9.8 & {$[41]$} \\
\hline 1.1 & $*$ & $*$ & $*$ & $*$ & & \\
\hline
\end{tabular}

Table 7: Major elements composition of Municipal solid wastes (mg/kg).

The highest minor elemental ions in the three batches were $\mathrm{Fe}, \mathrm{Al}, \mathrm{Cu}, \mathrm{Zn}$, and $\mathrm{Mn}$, for the first batch respectively. The concentrations of these minor elements found in this study have been compared with previous reports as shown in Table 8.

\begin{tabular}{|c|c|c|c|c|c|c|c|c|c|c|c|c|c|c|c|c|c|c|c|c|c|c|}
\hline $\mathbf{B}^{3+}$ & $\mathbf{T i}^{\mathbf{3 +}}$ & $\begin{array}{c}\mathbf{A l}^{3} \\
+\end{array}$ & $\mathbf{V}^{2+}$ & $\begin{array}{c}\mathrm{Cr} \\
{ }_{6+}\end{array}$ & $\begin{array}{l}\mathbf{M} \\
\mathbf{n}^{2+}\end{array}$ & $\begin{array}{c}\mathbf{F e}^{2} \\
+\end{array}$ & $\begin{array}{c}\text { Co } \\
2+\end{array}$ & $\begin{array}{l}\mathbf{N i} \\
2+\end{array}$ & $\begin{array}{c}\mathbf{C} \\
\mathbf{u}^{2+}\end{array}$ & $\begin{array}{c}\mathbf{Z n} \\
2+\end{array}$ & $\begin{array}{l}\text { A } \\
\mathbf{s}^{3-}\end{array}$ & $\begin{array}{c}S \\
e^{3-}\end{array}$ & $\begin{array}{c}\mathbf{R} \\
\mathbf{b}^{\mathbf{3}} \\
-\end{array}$ & $\mathbf{S r}^{2-}$ & $\begin{array}{c}\mathbf{M} \\
\mathbf{o}^{3} \\
+\end{array}$ & $\begin{array}{l}\mathbf{A} \\
\mathbf{g}^{+}\end{array}$ & $\begin{array}{c}\mathrm{C} \\
\mathrm{d}^{2} \\
+\end{array}$ & $\begin{array}{c}\text { Cs } \\
+\end{array}$ & $\begin{array}{c}\text { Ba } \\
2+\end{array}$ & $\begin{array}{c}\mathbf{P b} \\
+\end{array}$ & $\mathbf{U}^{4+}$ & $\begin{array}{c}\text { Referen } \\
\text { ces }\end{array}$ \\
\hline $\begin{array}{c}41 . \\
6\end{array}$ & 21.9 & $\begin{array}{l}31 \\
21\end{array}$ & $\begin{array}{c}23 . \\
9\end{array}$ & 16 & $\begin{array}{l}39 \\
7.7\end{array}$ & $\begin{array}{l}38 \\
52\end{array}$ & $\begin{array}{c}11 . \\
3\end{array}$ & $\begin{array}{c}93 . \\
5\end{array}$ & $\begin{array}{l}18 \\
45\end{array}$ & $\begin{array}{l}61 \\
2.7\end{array}$ & 3 & $\begin{array}{l}0 . \\
1\end{array}$ & $\begin{array}{l}2 . \\
3\end{array}$ & 63.4 & $\begin{array}{l}3 . \\
4\end{array}$ & $\begin{array}{l}3 . \\
2\end{array}$ & $\begin{array}{r}33 \\
.9\end{array}$ & 0.2 & $\begin{array}{l}29 \\
1.2\end{array}$ & $\begin{array}{l}16 \\
1.2\end{array}$ & $\begin{array}{l}0.2 \\
37\end{array}$ & $\begin{array}{l}\text { First } \\
\text { batch }\end{array}$ \\
\hline 6.2 & 12.2 & $\begin{array}{l}18 \\
77\end{array}$ & $\begin{array}{c}26 . \\
3\end{array}$ & 26 & $\begin{array}{l}12 \\
0.4\end{array}$ & $\begin{array}{l}32 \\
59\end{array}$ & 1.8 & $\begin{array}{c}12 . \\
7\end{array}$ & $\begin{array}{l}12 \\
2.1\end{array}$ & $\begin{array}{l}34 \\
6.8\end{array}$ & $\begin{array}{l}1 . \\
6\end{array}$ & $\begin{array}{l}0 . \\
2\end{array}$ & $\begin{array}{l}1 . \\
7\end{array}$ & 44.7 & $\begin{array}{l}1 . \\
2\end{array}$ & $\begin{array}{l}0 . \\
5\end{array}$ & $\begin{array}{l}1 . \\
4\end{array}$ & 0.1 & $\begin{array}{c}62 . \\
9\end{array}$ & $\begin{array}{l}12 \\
3.7\end{array}$ & 0.2 & $\begin{array}{c}\text { Second } \\
\text { batch }\end{array}$ \\
\hline 7 & 12.5 & $\begin{array}{l}19 \\
54\end{array}$ & $\begin{array}{c}26 . \\
7\end{array}$ & $\begin{array}{c}26 . \\
9\end{array}$ & $\begin{array}{l}13 \\
7.2\end{array}$ & $\begin{array}{l}28 \\
17\end{array}$ & 1.8 & $\begin{array}{c}12 . \\
4\end{array}$ & $\begin{array}{c}70 . \\
4\end{array}$ & $\begin{array}{l}38 \\
8.9\end{array}$ & $\begin{array}{l}1 . \\
6\end{array}$ & $\begin{array}{l}0 . \\
1\end{array}$ & $\begin{array}{l}1 . \\
9\end{array}$ & 45.9 & $\begin{array}{l}1 . \\
2\end{array}$ & $\begin{array}{l}0 . \\
6\end{array}$ & $\begin{array}{l}2 . \\
6\end{array}$ & 0.1 & 62 & $\begin{array}{c}12 \\
3.4\end{array}$ & 0.2 & $\begin{array}{l}\text { Third } \\
\text { batch }\end{array}$ \\
\hline$*$ & 9300 & \#\# & 40 & 30 & 47 & 12 & $*$ & 14 & 65 & 59 & * & $*$ & 30 & 370 & $*$ & $*$ & 72 & $*$ & $*$ & 90 & $*$ & [42] \\
\hline
\end{tabular}




\begin{tabular}{|c|c|c|c|c|c|c|c|c|c|c|c|c|c|c|c|c|c|c|c|c|c|c|}
\hline & & \#\# & & 0 & 0 & 30 & & 0 & 0 & 00 & & & & & & & 0 & & & 0 & & \\
\hline$*$ & $*$ & $\begin{array}{c}35 . \\
7\end{array}$ & $*$ & $\begin{array}{c}0.1 \\
8\end{array}$ & $\begin{array}{c}0.7 \\
4\end{array}$ & $\begin{array}{c}22 . \\
9\end{array}$ & $*$ & $*$ & $\begin{array}{c}0.5 \\
5\end{array}$ & $\begin{array}{c}5.2 \\
5\end{array}$ & $*$ & $*$ & $*$ & $*$ & $*$ & $*$ & $\begin{array}{c}0 . \\
06 \\
\end{array}$ & $*$ & $*$ & $\begin{array}{c}2.1 \\
5\end{array}$ & $*$ & [40] \\
\hline$*$ & $*$ & $\begin{array}{c}19 \\
21 \\
0\end{array}$ & $*$ & 72 & $\begin{array}{c}30 \\
9\end{array}$ & $\begin{array}{l}52 \\
40\end{array}$ & 14 & 22 & $\begin{array}{c}57 \\
0\end{array}$ & $\begin{array}{l}62 \\
88\end{array}$ & $*$ & $*$ & $*$ & 151 & $*$ & $*$ & 95 & $*$ & $\begin{array}{c}53 \\
9\end{array}$ & $\begin{array}{l}20 \\
00\end{array}$ & $*$ & [17] \\
\hline$*$ & $*$ & $*$ & $*$ & $\begin{array}{c}31 \\
8.4\end{array}$ & $*$ & $*$ & $\begin{array}{l}36 . \\
94\end{array}$ & $\begin{array}{c}18 \\
5.7\end{array}$ & $\begin{array}{l}97 \\
6.7\end{array}$ & $\begin{array}{l}60 \\
90\end{array}$ & $\begin{array}{l}8 \\
2 . \\
4\end{array}$ & $*$ & $*$ & $*$ & $*$ & $\begin{array}{l}1 \\
1 . \\
7 \\
5\end{array}$ & $\begin{array}{c}72 \\
.0 \\
2\end{array}$ & $*$ & $*$ & $\begin{array}{l}47 \\
70\end{array}$ & $*$ & [58] \\
\hline$*$ & $*$ & $\begin{array}{l}18 \\
60\end{array}$ & $*$ & & 71 & $\begin{array}{l}22 \\
00\end{array}$ & $*$ & $*$ & $\begin{array}{c}32 \\
6\end{array}$ & $\begin{array}{l}78 \\
90\end{array}$ & $*$ & $*$ & $*$ & 185 & $*$ & $*$ & & $*$ & $*$ & $\begin{array}{l}20 \\
70\end{array}$ & $*$ & [40] \\
\hline$*$ & $*$ & $*$ & $*$ & $\begin{array}{l}36 \\
6.2\end{array}$ & $*$ & $\begin{array}{c}0.4 \\
4\end{array}$ & $*$ & $\begin{array}{l}74 . \\
85\end{array}$ & $\begin{array}{l}12 \\
86\end{array}$ & $\begin{array}{l}56 \\
22\end{array}$ & $\begin{array}{l}1 \\
3 \\
1\end{array}$ & $*$ & $*$ & $*$ & $*$ & $*$ & $\begin{array}{c}28 \\
9 . \\
7\end{array}$ & $*$ & $*$ & $\begin{array}{l}44 \\
51\end{array}$ & $*$ & [93] \\
\hline$*$ & $*$ & $*$ & $*$ & $\begin{array}{l}16 \\
57\end{array}$ & $*$ & $\begin{array}{c}0.1 \\
2\end{array}$ & $*$ & $\begin{array}{l}55 \\
4.9\end{array}$ & $\begin{array}{l}26 \\
41\end{array}$ & $\begin{array}{l}71 \\
18\end{array}$ & $\begin{array}{l}2 \\
9 \\
5\end{array}$ & $*$ & $*$ & $*$ & $*$ & $*$ & $\begin{array}{l}15 \\
96\end{array}$ & $*$ & $*$ & $\begin{array}{l}67 \\
93\end{array}$ & $*$ & [93] \\
\hline$*$ & 0.8 & 2.6 & $*$ & $\begin{array}{c}33 \\
2\end{array}$ & $\begin{array}{c}68 \\
0\end{array}$ & $*$ & $*$ & $*$ & $\begin{array}{l}16 \\
53\end{array}$ & 3 & $*$ & $*$ & $*$ & $*$ & $*$ & $*$ & $\begin{array}{c}62 \\
9\end{array}$ & $*$ & $*$ & $\begin{array}{c}75 \\
8\end{array}$ & $*$ & [41] \\
\hline$*$ & $*$ & $*$ & $*$ & $\begin{array}{c}32 \\
6\end{array}$ & $\begin{array}{l}20 \\
35\end{array}$ & $*$ & $*$ & $*$ & $\begin{array}{l}10 \\
48\end{array}$ & $\begin{array}{l}62 \\
40\end{array}$ & $*$ & $*$ & $*$ & $*$ & $*$ & $*$ & $\begin{array}{l}47 \\
.5\end{array}$ & $*$ & $*$ & $\begin{array}{l}13 \\
93\end{array}$ & $*$ & [94] \\
\hline$*$ & $*$ & $*$ & $*$ & $\begin{array}{c}36 \\
5\end{array}$ & & $*$ & $*$ & $*$ & $\begin{array}{c}23 \\
7\end{array}$ & $\begin{array}{c}65 \\
0\end{array}$ & $*$ & $*$ & $*$ & $*$ & $*$ & $*$ & 2 & $*$ & $*$ & $\begin{array}{c}23 \\
5\end{array}$ & $*$ & [95] \\
\hline$*$ & $*$ & $*$ & $*$ & $\begin{array}{c}0.0 \\
7\end{array}$ & $\begin{array}{c}0.0 \\
5\end{array}$ & $*$ & $*$ & $*$ & $\begin{array}{c}0.0 \\
6\end{array}$ & 1.7 & $*$ & $*$ & $*$ & $*$ & $*$ & $*$ & $\begin{array}{c}0 . \\
03\end{array}$ & $*$ & $*$ & 0.8 & $*$ & [96] \\
\hline$*$ & 1.1 & $*$ & $*$ & $\begin{array}{c}0.0 \\
6\end{array}$ & $*$ & $*$ & $*$ & $\begin{array}{l}0.0 \\
14\end{array}$ & $\begin{array}{c}0.0 \\
9\end{array}$ & 2.7 & $*$ & $*$ & $*$ & $*$ & $*$ & $*$ & $\begin{array}{l}0 . \\
04\end{array}$ & $*$ & $*$ & 0.8 & * & [71] \\
\hline$*$ & $*$ & $*$ & $*$ & $\begin{array}{c}93 . \\
5\end{array}$ & $*$ & $*$ & $*$ & & & & $*$ & $*$ & $*$ & $*$ & $*$ & $*$ & $\begin{array}{l}13 \\
.5\end{array}$ & $*$ & $*$ & $\begin{array}{l}16 \\
3.4\end{array}$ & $*$ & [33] \\
\hline$*$ & $*$ & 7 & $*$ & $\begin{array}{c}0.0 \\
7\end{array}$ & $\begin{array}{c}0.0 \\
77\end{array}$ & 2.8 & $*$ & $\begin{array}{c}0.0 \\
14\end{array}$ & $\begin{array}{c}0.1 \\
1\end{array}$ & 3.1 & $*$ & $*$ & $*$ & $*$ & $*$ & $*$ & $\begin{array}{l}0 . \\
04\end{array}$ & $*$ & $*$ & $\begin{array}{c}0.8 \\
9\end{array}$ & $\begin{array}{c}3.0 \\
5\end{array}$ & [27] \\
\hline$*$ & 6100 & $\begin{array}{l}\# \# \\
\# \#\end{array}$ & $*$ & $\begin{array}{c}49 \\
4\end{array}$ & $\begin{array}{c}44 \\
8\end{array}$ & $\begin{array}{l}16 \\
00\end{array}$ & $\begin{array}{c}13 . \\
3\end{array}$ & $\begin{array}{c}69 . \\
8\end{array}$ & $\begin{array}{l}22 \\
20\end{array}$ & $*$ & $\begin{array}{l}9 \\
6 \\
0\end{array}$ & $\begin{array}{l}1 \\
7 . \\
4\end{array}$ & $\begin{array}{c}20 \\
6\end{array}$ & $*$ & $\begin{array}{l}4 \\
7 . \\
1\end{array}$ & $*$ & $\begin{array}{l}19 \\
90\end{array}$ & $*$ & $\begin{array}{l}24 \\
00\end{array}$ & $\begin{array}{c}27 \\
00 \\
0\end{array}$ & $*$ & [39] \\
\hline
\end{tabular}

Table 8: Minor elements in municipal solid waste ( $\mathrm{mg} / \mathrm{kg})$.

Fe level was the highest amongst other minor metals which agrees with published reports which has found that $\mathrm{Fe}$ represented more than 50\% of the total metals present in MSW samples [45].The second highest elemental ion in this study was $\mathrm{Al}$, which is another important metal present in can, foils, etc. Some types of plastic and glass packaging contain high levels of heavy metals and contribute heavily to their total output $[45,46]$. 
Comparing data with other studies, concentrations of $\mathrm{Fe}$ and $\mathrm{Al}$ were $[42,17]$. However, the concentrations of the other metal ions were similar to those previously reported (Table 8). When looking at the presence of minor elements, samples of MSW analysed here contained more lithophilic elements such as $\mathrm{Ca}$, and $\mathrm{Al}$ and contained less volatile elements such as $\mathrm{K}, \mathrm{Na}, \mathrm{Cd}, \mathrm{Zn}$ and $\mathrm{Pb}$ than some other studies. This relative enrichment is probably due to the high combustion temperature and excellent burnout at the MSW incineration facility [47].

MSW could be used for compost production as it contains garden, food and household wastes and has been shown to have a biodegradable proportion varying from 50\% to $90 \%$ depending upon the country [32].Currently in the UK, the biodegradable content is estimated at $68 \%$ but is predicted to fall to $54 \%$ by 2020 due to increased collection of source-segregated waste [48].

Compost derived from heterogeneous MSW has a 50-70\% component which is potentially biodegradable [32]. However, the compost is currently excluded from UK composting standards [49], also there are restrictions in many countries on landfill sites if MSW does not meet quality standards [50]. Reasons behind these restrictions are that even with excellent separation and pre-treatment some contaminants such as glass shards and plastic fragments are not biodegradable. In addition, presence of other contaminations such as heavy metals (e.g., $\mathrm{Cd}, \mathrm{Cr}, \mathrm{Cu}, \mathrm{Pb}, \mathrm{Ni}$ and $\mathrm{Zn})$ can be a reason for the exclusion especially if applied to arable land for food production [35, 51].

For composting MSW there are three main stages the first stage is 'sanitization' which depends on a vigorous aeration regime to accelerate microbial breakdown of substrates, this stage is a necessary stage for most compost standards to ensure destruction of both plant and animal pathogens; Consequently, a secondary biodegradation phase of $45-55^{\circ} \mathrm{C}$ is used to facilitate rapid substrate degradation [52-54]. The tertiary phase is similar for both aerated and turned compost, but requires little active management, this stage helps convert potential toxic $\mathrm{NH}_{4}$ to $\mathrm{NO}_{3}$; allowing loss of phytotoxic volatile compounds and stabilization of the microbial community. This tertiary phase also helps to the breakdown and transformation of humic substances and lignin by mesophilic fungi and actinomycetes [55, 56]. The effectiveness of bioleaching is highly dependent on the physical, chemical and biological factors in the system including: carbon and oxygen supply, $\mathrm{pH}$, temperature; pre-culture period and inoculum, microorganism's resistance, solid residue composition, solid liquid ratio, and bioleaching period [57].

In the current study, assessing the efficiency of chemical leaching it was observed that addition of $\mathrm{H}_{2} \mathrm{SO}_{4}$ and gluconic acid gave a higher retained\% yield when compared with other acids used in this study, this observation has been reported previously where organic acid correlated with increases in the yield [58,59]. Using commercial organic acid as a leaching agent has been shown to correlate with removal of heavy metals [28].

In the present study, the current experiment focused on the biological processes such as using various fungi and optimising conditions to optimise bioleaching defined here as\% yield. The S/L ratio was selected since in the literature it has been shown that optimum S/L ratio for bioleaching of MSW using A. niger was 10-20 g/L (MSW mass to culture medium volume) $[17,27,28,43]$. Increasing the solid in the reactor did not improve leaching 
presumably due to this fungi's sensitivity to the presence of heavy metals. For this reason bioleaching technology has been difficult to apply on an industrial scale [40]and use of a higher mass content of fly ash leads to lower yields of extracted heavy metals [28].

Selecting best fungi for leaching heavy metals using artificial medium, mechanisms which lead to microorganisms facilitating mineral biooxidation and bioleaching have been termed contact and non-contact [60]. Adding microbes has been shown to facilitate the process by localising ferric ions in the exopolymeric material at the mineral surface [61]. Furthermore, fungi have been shown to interact with metals by blocking the functional group of enzymes depending on the type of metal and the organism [62-64], leading to an increase in the tolerance of fungi for bioleaching [40].

In the present study, it was determined that $A$. niger was the best fungi in terms of bioleaching heavy metals, this has been observed previously $[62,65]$. It has been shown that A. niger is more resistant than other fungi for bioleaching [57]. Organisms under environmental stress have been shown to develop various mechanisms in order to cope with adverse conditions. In fungi, severe stresses has been shown to be tolerated by inherent physiological characteristics or by adaptation through temporary alteration in their developmental pattern as demonstrated in detoxification of fly ash MSW using A. niger [27, 66]. Therefore, A. niger is a heterotrophic fungus which has become associated with improved tolerance to unfavorable conditions $[24,67,68]$.

In the present study, two bioleaching methods were compared (one and two way method), results indicated that element retained yield\% following a one-step bioleaching method (fungi added at the start of the incubation) was higher than in two step bioleaching (fungi added after an initial incubation of MSW and medium). In assays, using $10 \mathrm{~g} / \mathrm{L}$ MSW concentrations results agreed with reports previously published [28]. Use of a two-way method was characterised by relatively poor bioleaching and a possible mechanism for this is that calcium oxalate hydrate precipitation in two-step bioleaching was similar to that of one-step bioleaching, however, the on-set of the distortion and swollen structure of the hyphae occurs earlier in a two-step bioleaching when compared with one-step leaching. Despite this, the bioleaching effects appear insignificant because of production of organic acid during a two way method before addition of fly ash and exposure to toxic conditions [69].

Artificial media have been applied over many years for the removal of metals from MSW and other contaminated samples. However, the cost of pure glucose or sucrose for the process can raise the cost of compost or fertiliser [70] for this reason in this study, two non-artificial media were studied; (clay and sorghum). In terms of artificial media, the glucose composition can vary $(24-42 \mathrm{~g} / \mathrm{L})[71,72]$.

The $\mathrm{pH}$ value is also a very important parameter in determining the bioleaching efficiency since the $\mathrm{pH}$ changes at different substrate densities [73]. In the present study, results showed that clay medium inoculated for $\mathrm{pH} 5.5$ correlated with better performance in terms of getting lowest retaining yield\% of elements in MSW when compared with other media so the clay showed the best performance, probably because of clay's ability to adsorb metals. 
Research has revealed that the main attempts for the effective application of red mud are: soil amendment to prevent nutrient loss and reduce heavy metal availability; adsorbents for removal of heavy metal ions and metalloid ions [73, 74, 75]. In addition clay being mostly composed of minerals stands out because of its high potential to bind heavy metals $[76,77]$. Soils having granulometric composition which are characteristics for clay, silt and dust, and those with a high content of organic matter, have a higher absorption capacity and a higher ability to bind metallic elements. Generally, all soils with high absorption capacity for cations, i.e. land containing a large amount of clay minerals, have the ability to accumulate metallic elements [77-79].

Results observed here did not agree with published reports which showed clay had a negative effects on metals removing from waste, this may be due to minerals present in clay that may migrate with the leaching solution to the bottom of a heap and restrict water flow and access of oxygen [80]; also clay contains metals and has dense particles which have been shown to inhibit fungal growth. Addition of clay also changes the $\mathrm{pH}$ of the media to a more alkaline solution; a more alkaline medium has been correlated with a reduced extraction yield [17].

In assays with a starting $\mathrm{pH}$ of 2.5 , addition of sorghum medium correlated with highest retained yield\% (best performance), this result maybe as a result of sorghum hydrolysate being rich in carbon source and its concentration is important for bioleaching as it not only supports microbial growth but also influences the yield of organic acids which are potentially active compounds in bioleaching [81]. In the case of A. niger for instance, sucrose as a carbon source has been reported to give a higher yield of organic acids than other sugars such as fructose, lactose and galactose [82]. However, paucity of organic carbon, nitrogen and micronutrients will also limit microbial growth [83-85].

In this study, assays with a starting $\mathrm{pH}$ of 2.5 were better than 5.5, this effect may be due to the fact that glucose oxidase has an optimum $\mathrm{pH}$ at 4.5-6.5 and is inactivated at a pH below 3.0 [86]. Presence of fly ash also increased the $\mathrm{pH}$ of the system, and thus activates the enzyme glucose oxidase which converts glucose to hydrogen peroxide, and finally hydrolyses it to gluconic acid [73].

The study was examined that the bio-produced organic acids was the most important leaching agent in the bioleaching process using fungi [62]. Fungal bioleaching is based on four mechanisms: acidolysis, complexolysis, redoxolysis and bioaccumulation [27, 87]. As the first three processes are mediated through the secondary metabolites produced by the fungus, it is important to determine these metabolites (organic acids) in order to better understand the bioleaching mechanisms [16]. These might also represent valuable compounds if present at high enough levels. Commonly A. niger is used for the production of organic acids (citric and gluconic acid) for commercial purpose and production is significantly related to $\mathrm{pH}$ and presence of metals in the medium [81, 88, 89]. The present study showed that gluconic acid to be the most effective organic acid produced the study agree with [27], Concentration of oxalic acid was quite low in all cases and this has been seen previously [90] and the lowest acid production was citric acid [69]. Assays with A. niger at a starting $\mathrm{pH}$ of both 5.5 and 2.5 were characterised by production of gluconic acid as the highest by product, then oxalic acid and finally citric acid. At $\mathrm{pH} 6$ A. niger 
causes to accumulate gluconic acid by inhibiting citric acid secretion [81]. Studies have shown that using A. niger and fly ash produced gluconic acid instead of citric acid due to the inhibition of enzymes in the TCA cycle by manganese. Addition of A. niger has been shown to be especially effective for the leaching of lead from fly ash [27]. The presence of metal ions, such as $\mathrm{Zn}^{2+}, \mathrm{Mn}^{2+}, \mathrm{Fe}^{2+}$ and $\mathrm{Co}^{2+}$ in fly ash has been shown to inhibit the accumulation of citric acid and promote formation of gluconic acid [22, 91], in particular the presence of manganese is reported to strongly inhibit citric acid production [81]. When fly ash was inoculated with spores in an acid medium the alkaline calcium oxide present in the ash was hydrated to form calcium hydroxide which increased the $\mathrm{pH}$, the alkaline medium activates glucose oxidase which converts glucose to gluconolactone which is finally hydrolyzed to gluconic acid [86]. Furthermore, the preliminary study on the characterisation of MSW in the present study, showed that the $\mathrm{pH}$ was 6.8 .

Assays revealed that use of a starting $\mathrm{pH}$ of 2.5 was characterised by increased production of organic acid when comparing with assays with a starting $\mathrm{pH}$ of 5.5, especially in terms of gluconic acid. Organic acid production increasing as $\mathrm{pH}$ drops has been observed previously [17, 27]. Organic acids are protonated at low $\mathrm{pH}$ and hence are membrane permeable, inside the neutral $\mathrm{pH}$ cytoplasm, the molecule dissociate, releasing protons and acidifying the cell [91]. There was a reduction in gluconic acid and citric acid levels towards the end of the incubation period. This may be associated with the consumption of the acid in the bioleaching process as well as a drop in the organic acid production, caused by the decrease in the fungus growth rate. It was noted that there was an increase in metal leaching as organic acid production increased (mainly gluconic acid). So depletion of bioleaching agents could be one reason behind a decrease in the rate of metal extraction as has been suggested previously [62].

\begin{tabular}{|c|c|c|c|c|c|c|c|c|c|c|}
\hline & \multicolumn{2}{|c|}{ Substrate $/$ standard $(\mathrm{mg} / \mathrm{kg})$} & $\mathrm{Cd}^{2+}$ & $\mathrm{Cu}^{2+}$ & $\mathrm{Cr}^{6+}$ & $\mathrm{Hg}$ & $\mathrm{Ni}^{2+}$ & $\mathbf{P b}^{2+}$ & $\mathbf{Z n}^{2+}$ & $\begin{array}{l}\text { Reference } \\
s\end{array}$ \\
\hline \multirow{4}{*}{$\begin{array}{c}\text { Standard } \\
\text { s }\end{array}$} & \multicolumn{2}{|c|}{ UK Compost standards } & 1.5 & 200 & 100 & 1 & 50 & 200 & 400 & [49] \\
\hline & \multicolumn{2}{|c|}{ Italian compost standards } & 3 & 300 & & 3 & 100 & 280 & 1000 & [50] \\
\hline & \multicolumn{2}{|c|}{ Green wastes compost } & 1.4 & 51 & 46 & 0.5 & 22 & 87 & 186 & [50] \\
\hline & \multicolumn{2}{|c|}{ Bio-waste compost } & 0.9 & 96 & 26 & 0.6 & 24 & 86 & 289 & {$[50]$} \\
\hline \multirow{3}{*}{$\begin{array}{c}\text { MSW } \\
\text { sample }\end{array}$} & MSW & $\begin{array}{l}\text { Unpretreated } \\
\text { (origional) }\end{array}$ & 33.9 & 1844.9 & 16 & $*$ & 93.4 & 161.2 & 612 & [50] \\
\hline & MSW & water & 22.6 & 344.5 & 9.9 & & 26.5 & 110.6 & 370.1 & \\
\hline & $\begin{array}{c}\text { Sorghum } \\
\text { Med. } \mathrm{pH} \\
2.5\end{array}$ & A. niger & 10.8 & 504 & 5.8 & $*$ & 15.4 & 69.1 & 137.18 & - \\
\hline
\end{tabular}

Table 9: Shows a comparison of the optimised bioleaching condition results using fungi against the regulatory level $(\mathrm{mg} / \mathrm{kg})$. 
Toxicity of composts following fungal bioleaching are shown in Table 9, results revealed that fungi process almost reached the environmentally acceptable standards.

\section{Conclusion}

The final experiment applied using MSW was to examine how growth of fungi could correlate with removal of heavy metals from MSW. It was determined that the best fungus for bioleaching of elements was A. niger using a one-step method and an artificial medium. Artificial medium was chosen as a means of reducing the cost of bioleaching rather than using pure glucose assays using mediums such as hydrolysates extracted from sorghum, and clay were characterised by good bioleaching and assays to determine optimal $\mathrm{pH}$ revealed that $\mathrm{pH} 5.5 \mathrm{was}$ optimum for clay to remove metals from MSW whereas $\mathrm{pH} 2.5$ was optimum for addition of sorghum showed a lowest retained yield $\%$. Elements bioleaching (\% yield) has been calculated during the process and correlated with production of organic acids as by-products, assays determined that gluconic acid as a highest concentration when comparing with the other organic acids. Use of $\mathrm{H}_{2} \mathrm{SO}_{4}$ acid as a chemical leaching agent was characterised by better retaining yield\% than other organic acids.

\section{Acknowledgments}

The authors gratefully acknowledge the financial support by the Salahaddin University Iraq-Kurdistan region for providing Jwan J. Abdullah's PhD Scholarship and funding this research. We also thank the Biotechnology and Biological Sciences Research Council (BBSRC, BB/G01616X/1) for supporting this research.

\section{References}

1. Alhassan M. Effect of Municipal Solid Waste on Geotechnical Properties of Soils. International Journal of Environmental Science, Management and Engineering Research 1 (2012): 204-210.

2. Kumar D, and Alappat B. Monitoring leachate composition at a municipal landfill site in New Delhi, India. International journal of environment and pollution 19 (2003): 454-465.

3. Schwarz-Herion O, Omran A, Rapp HP. A case study on successful municipal solid waste management in industrialized countries by the example of karlsruhe city, germany. J Engineering Annals of Faculty of Engineering Hunedoara 5 (2008): 266-273.

4. Kimani NG. Environmental pollution and impacts on public health: implications of the Dandora Munipal Dumping site in Nairobi, Kenya: Report Summary (2014).

5. Alam P, Ahmade K. Impact of solid waste on health and the environment. International Journal of Sustainable Development and Green Economics (IJSDGE) 2 (2013): 165-168.

6. Phil-Eze P. Variability of soil properties related to vegetation cover in a tropical rainforest landscape. Journal of Geography and Regional Planning 3 (2010): 177-184.

7. Shayler H, McBride M, Harrison E. Cornell Waste Management Institute (2009).

8. Leifeld J, Siebert S, Kögel-Knabner I. Biological activity and organic matter mineralization of soils amended with biowaste composts. Journal of Plant Nutrition and Soil Science 165 (2002): 151-159. 
9. Özsoy G. An investigation of agricultural use potential of wastewater sludges in Turkey with respect to heavy metals and pathogens. Middle East technical university (2006).

10. Lu Q, He ZL, Stoffella PJ. Land application of biosolids in the USA: A review. Applied and Environmental Soil Science.(2012).

11. TRENCH OB. Biosolids (2002).

12. Lopes WS, Leite VD, Prasad S. Influence of inoculum on performance of anaerobic reactors for treating municipal solid waste. Bioresource technology 94 (2004): 261-266.

13. Guerrero A, Fernández E, Macias A, Goni S. Hydrothermal treatment of fly ash from municipal solid waste incineration. Waste Management Series 1 (2000): 178-185.

14. Zhang FS, Itoh H. A novel process utilizing subcritical water and nitrilotriacetic acid to extract hazardous elements from MSW incinerator fly ash. Science of the total environment 369 (2006): 273-279.

15. Nagib S, Inoue K. Recovery of lead and zinc from fly ash generated from municipal incineration plants by means of acid and/or alkaline leaching. Hydrometallurgy 56 (2000): 269-292.

16. Hong K, Tokunaga S, Ishigami $\mathrm{Y}$, et al. Extraction of heavy metals from MSW incinerator fly ash using saponins. Chemosphere 41 (2000): 345-352.

17. Wu HY, Ting YP. Metal extraction from municipal solid waste (MSW) incinerator fly ash-Chemical leaching and fungal bioleaching. Enzyme and microbial technology 38 (2006): 839-847.

18. Ehrlich H. Microbes and metals. Applied microbiology and biotechnology 48 (1997): 687-692.

19. Chen SY, Lin JG. Influence of solid content on bioleaching of heavy metals from contaminated sediment by Thiobacillus spp. Journal of chemical technology and biotechnology 75 (2000): 649-656.

20. Ilya S, Anwar MA, Niazi SB, et al. Bioleaching of metals from electronic scrap by moderately thermophilic acidophilic bacteria. Hydrometallurgy 88 (2007): 180-188.

21. Simate S, Ndlovu S, Walubita LF. The fungal and chemolithotrophic leaching of nickel lateritesChallenges and opportunities. Hydrometallurgy 103 (2010): 150-157.

22. Burgstaller W, Schinner F. Leaching of metals with fungi. Journal of Biotechnology 27 (1993): 91-116.

23. Castro ID, Fietto JL, Vieira RX, et al. Bioleaching of zinc and nickel from silicates using Aspergillus niger cultures. Hydrometallurgy 57 (2000): 39-49.

24. Ren WX, Li PJ, Geng Y, et al. Biological leaching of heavy metals from a contaminated soil by Aspergillus niger. Journal of Hazardous Materials 167 (2009): 164-169.

25. Abdullah J, Darren G, Nattha P, et al. Optimizing cellulase production from Municipal Solid Waste (MSW) using solid state fermentation(SSF). Fundamentals Renewable Energy and Applications. (2016).

26. Kimbrough DE, Wakakuwa JR. Acid digestion for sediments, sludges, soils, and solid wastes. A proposed alternative to EPA SW 846 Method 3050. Environmental science and technology 23 (1989): 898-900.

27. Bosshard PP, Bachofen R, Brandl H. Metal leaching of fly ash from municipal waste incineration by Aspergillus niger. Environmental science and technology 30 (1996): 3066-3070.

28. Wang Q, Wang Q, Wu T. Comparisons of one-step and two-step bioleaching for heavy metals removed from municipal solid waste incineration fly ash. Environmental Engineering Science 25 (2008): 783-789. 
29. O'Dell BL, Sunde RA. Handbook of nutritionally essential mineral elements: CRC Press (1997).

30. Richard TL, Woodbury PB. The impact of separation on heavy metal contaminants in municipal solid waste composts. Biomass and bioenergy 3 (1992): 195-211.

31. Slack RJ, Bonin M, Gronow R, et al. Household hazardous waste data for the UK by direct sampling. Environmental science and technology 41 (2007): 2566-2571.

32. Déportes I, Benoit-Guyod JL, Zmirou D. Hazard to man and the environment posed by the use of urban waste compost: a review. Science of the total environment 172 (1995): 197-222.

33. Hasselriis F, Licata A. Analysis of h3eavy metal emission data from municipal waste combustion. Journal of Hazardous Materials47 (1996): 77-102.

34. Slack R, Gronow J, Voulvoulis N. Hazardous components of household waste. Critical reviews in environmental science and technology 34 (2004): 419-445.

35. Farrell M, Jones D. Critical evaluation of municipal solid waste composting and potential compost markets. Bioresource technology 100 (2009): 4301-4310.

36. Roane TM, Pepper I. Microorganisms and metal pollutants. Environmental microbiology (2000): 403-423.

37. Hasselriis F. Analysis of data obtained from an historic ash residue leaching investigation. Paper presented at the National waste progressing conference (1994).

38. Abanades S, Flamant G, Gagnepain B, et al. Fate of heavy metals during municipal solid waste incineration. Waste management and research 20 (2002): 55-68.

39. Eighmy TT, Eusden JD, Krzanowski JE, et al. Comprehensive approach toward understanding element speciation and leaching behavior in municipal solid waste incineration electrostatic precipitator ash. Environmental science \& technology 29 (1995): 629-646.

40. Yang J, Wang Q, Wu T. Heavy metals extraction from municipal solid waste incineration fly ash using adapted metal tolerant Aspergillus niger. Bioresource technology 100 (2009): 254-260.

41. Park YJ, Heo J. Vitrification of fly ash from municipal solid waste incinerator. Journal of Hazardous Materials 91 (2002): 83-93.

42. Rodella N, Bosio A, Dalipi R, et al. Waste silica sources as heavy metal stabilizers for municipal solid waste incineration fly ash. Arabian Journal of Chemistry (2014).

43. Xu TJ, Ting YP. Optimizations on bioleaching of incinerator fly ash by Aspergillus niger-use of central composite design. Enzyme and microbial technology 35 (2004): 444-454.

44. Quina MJ, Bordado JC, Quinta-Ferreira RM. Percolation and batch leaching tests to assess release of inorganic pollutants from municipal solid waste incinerator residues. Waste management 31 (2011): 236245.

45. Verma S. Anaerobic digestion of biodegradable organics in municipal solid wastes. Columbia University (2002).

46. Dien BS, Jung HJG, Vogel KP, et al. Chemical composition and response to dilute-acid pretreatment and enzymatic saccharification of alfalfa, reed canarygrass, and switchgrass. Biomass and bioenergy 30 (2006): 880-891. 
47. Li M, Xiang J, Hu S, et al. Characterization of solid residues from municipal solid waste incinerator. Fuel 83 (2004): 1397-1405.

48. SU. Waste not, want not. A strategy for tackling the waste problem in England. London, UK.: Strategy Unit, Cabinet Office (2002).

49. BSI. PAS 100 Specifications for Composted Materials. British Standards Institution, London (2005).

50. WRAP. Comparison of compost standards within the EU, North America and Australasia. Banbury, Oxford, UK: The Waste and Resources Action Programme (2002).

51. Papadimitriou E, Barton J, Stentiford E. Sources and levels of potentially toxic elements in the biodegradable fraction of autoclaved non-segregated household waste and its compost/digestate. Waste management and research 26 (2008): 419-430.

52. Stentiford E. Composting control: principles and practice The science of composting (pp. 49-59): Springer (1996).

53. Abu Qdais H, Hamoda M. Enhancement of carbon and nitrogen transformations during composting of municipal solid waste. Journal of Environmental Science and Health, Part A 39 (2004): 409-420.

54. Deportes I, Benoit-Guyod J, Zmirou D et al. Microbial disinfection capacity of municipal solid waste (MSW) composting. Journal of Applied Microbiology 85 (1998): 238-246.

55. Swan JR, Crook B, Gilbert EJ. Microbial emissions from composting sites. Issues in environmental science and technology 18 (2002): 73-102.

56. Ozores-Hampton M, Stoffella PJ, Bewick TA, et al. Effect of age of composted MSW and biosolids on weed seed germination. Compost Science and Utilization 7 (1999): 51-57.

57. Bosecker K. Bioleaching: metal solubilization by microorganisms. FEMS Microbiology reviews20 (1997): 591-604.

58. Wang J, Chen C. Biosorption of heavy metals by Saccharomyces cerevisiae: a review. Biotechnology advances 24 (2006): 427-451.

59. Neale CN, Bricka R, Chao AC. Evaluating acids and chelating agents for removing heavy metals from contaminated soils. Environmental Progress 16 (1997): 274-280.

60. Rohwerder T, Gehrke T, Kinzler K, et al. Bioleaching review part A. Applied microbiology and biotechnology 63 (2003): 239-248.

61. Sand W, Gehrke T, Jozsa PG, et al (Bio) chemistry of bacterial leaching-direct vs. indirect bioleaching. Hydrometallurgy 59 (2001): 159-175.

62. Aung KMM, Ting YP. Bioleaching of spent fluid catalytic cracking catalyst using Aspergillus niger. Journal of Biotechnology 116 (2005): 159-170.

63. Gadd GM. Interactions of fungi with toxic metals The Genus Aspergillus. Springer (1994): 361-374

64. Gadd GM, Griffiths AJ. Microorganisms and heavy metal toxicity. Microbial Ecology 4 (1977): $303-317$.

65. Mulligan CN, Kamali M, Gibbs BF. Bioleaching of heavy metals from a low-grade mining ore using Aspergillus niger. Journal of Hazardous Materials 110 (2004): 77-84.

66. Nazareth S, Marbaniang T. Effect of heavy metals on cultural and morphological growth characteristics of halotolerant Penicillium morphotypes. Journal of basic microbiology 48 (2008): 363-369. 
67. Brandl H, Bosshard R, Wegmann M. Computer-munching microbes: metal leaching from electronic scrap by bacteria and fungi. Hydrometallurgy 59 (2001): 319-326.

68. Krishna P, Reddy MS, Patnaik S. Aspergillus tubingensis reduces the $\mathrm{pH}$ of the bauxite residue (red mud) amended soils. Water, air, and soil pollution 167 (2005): 201-209.

69. Xu TJ, Ramanathan T, Ting YP. Bioleaching of incineration fly ash by Aspergillus niger-precipitation of metallic salt crystals and morphological alteration of the fungus. Biotechnology Reports 3 (2014): 8-14.

70. Weber A, Thomas, JE, Skinner WM, et al. A methodology to determine the acid-neutralization capacity of rock samples. The Canadian Mineralogist 43 (2005): 1183-1192.

71. Krebs W, Brombacher C, Bosshard PP, et al. Microbial recovery of metals from solids. FEMS Microbiology reviews 20 (1997): 605-617.

72. Atlas RM. Bioremediation of petroleum pollutants. International Biodeterioration and Biodegradation 35 (1995): 317-327.

73. Qu Y, Lian B, Mo B, et al. Bioleaching of heavy metals from red mud using Aspergillus niger. Hydrometallurgy 136 (2013): 71-77.

74. Alva A, Huang B, Paramasivam S et al. Evaluation of root growth limiting factors in Spodic horizons of Spodosols. Journal of plant nutrition 25 (2002): 2001-2014.

75. Cengeloglu Y, Tor A, Ersoz M, et al. Removal of nitrate from aqueous solution by using red mud. Separation and Purification Technology 51 (2006): 374-378.

76. Sheoran V, Sheoran A, Poonia P. Phytomining: a review. Minerals Engineering 22 (2009): 1007-1019.

77. Fijałkowski K, Kacprzak M, Grobelak A et al. The influence of selected soil parameters on the mobility of heavy metals in soils. Inżynieria i Ochrona środowiska 15 (2012): 81-92.

78. Kavamura VN, Esposito E. Biotechnological strategies applied to the decontamination of soils polluted with heavy metals. Biotechnology advances 28 (2010): 61-69.

79. Gworek B, Barañski A, Czarnowski K, et al. Risk assessment in contaminated land management. institute Ochrony Środowiska, Warszawa (2000).

80. Olson G, Brierley J, Brierley C. Bioleaching review part B. Applied microbiology and biotechnology 63 (2003): 249-257.

81. Grewal H, Kalra K. Fungal production of citric acid. Biotechnology advances 13 (1995): 209-234.

82. Hossain M, Brooks J, Maddox I. The effect of the sugar source on citric acid production by Aspergillus niger. Applied microbiology and biotechnology 19 (1984): 393-397.

83. Gräfe M, Power G, Klauber C. Bauxite residue issues: III. Alkalinity and associated chemistry. Hydrometallurgy 108 (2011): 60-79.

84. Hamdy M, Williams F. Bacterial amelioration of bauxite residue waste of industrial alumina plants. Journal of Industrial Microbiology and Biotechnology 27 (2001): 228-233.

85. Thiyagarajan C, Phillips I, Dell B, et al. Micronutrient fractionation and plant availability in bauxiteprocessing residue sand. Soil Research 47 (2009): 518-528.

86. Dellweg H. Biotechnology. Weinheim: Verlag Chemie 3 (1983): 415-465. 
87. Schinner F, Burgstaller W. Extraction of zinc from industrial waste by a Penicillium sp. Applied and Environmental Microbiology 55 (1989): 1153-1156.

88. Karaffa L, Kubicek CP. Aspergillus niger citric acid accumulation: do we understand this well working black box? Applied microbiology and biotechnology 61 (2003): 189-196.

89. Roukas T. Citric and gluconic acid production from fig by Aspergillus niger using solid-state fermentation. Journal of Industrial Microbiology and Biotechnology 25 (2000): 298-304.

90. Kubicek C, Schreferl-Kunar G, Wöhrer W, et al. Evidence for a cytoplasmic pathway of oxalate biosynthesis in Aspergillus niger. Applied and Environmental Microbiology 54 (1988): 633-637.

91. Lee J, Pandey D. Bio-processing of solid wastes and secondary resources for metal extraction-a review. Waste management 32 (2012): 3-18.

92. Suzuki I, Lee D, Mackay B, et al. Effect of various ions, pH, and osmotic pressure on oxidation of elemental sulfur by Thiobacillus thiooxidans. Applied and Environmental Microbiology 65 (1999): 5163 5168. 